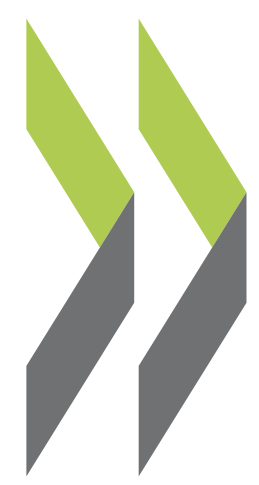

OECD Economics Department Working Papers No. 472

Product Market Reforms and Employment in OECD

Countries

\section{Giuseppe Nicoletti,} Stefano Scarpetta 
Organisation de Coopération et de Développement Economiques

Organisation for Economic Co-operation and Development

16-Dec-2005

ECONOMICS DEPARTMENT

English - Or. English

PRODUCT MARKET REFORMS AND EMPLOYMENT

IN OECD COUNTRIES

ECONOMICS DEPARTMENT WORKING PAPERS No. 472

By

Giuseppe Nicoletti and Stefano Scarpetta

(OECD and World Bank)

All Economics Department Working Papers are available through OECD's Internet Web site at www.oecd.org/eco 


\section{ABSTRACT/RESUMÉ \\ Product market reforms and employment in OECD countries}

We estimate the employment effects of product market reforms aimed at increasing competitive pressures and easing government controls in a sample of OECD countries over the past two decades. We control for several labour market policies and institutions that are thought to influence equilibrium employment rates, and check whether there are interactions between these policies and product market reforms. We find cross-country evidence that some labour and product market policies may be complementary and adjust for this in regressions. Consistent with the implications of the imperfect competition/bargaining model of Blanchard and Giavazzi (2003), our estimates suggest that restrictive regulations have curbed employment rates significantly in countries where no product market reforms were implemented. These effects appear to have been magnified by the interaction of such regulations with labour market settings that provide a strong bargaining power to insiders, suggesting that rent sharing tends to depress employment. The implication is that significant employment gains can be obtained by deregulating product markets in overly regulated countries. Moreover, these employment gains are likely to be higher in countries that have rigid labour markets.

JEL classification: J38, K20, L43

Keywords: product market regulation, labour market policies, employment performance, policy complementarity

\section{Effets sur l'emploi des réformes des marchés des biens et services dans les pays de l'OCDE}

Nous estimons l'impact sur l'emploi de réformes des marchés des biens et services augmentant la pression concurrentielle et allégeant le poids des règlementations, sur la base d'un échantillon de pays de l'OCDE et au cours des vingt dernières années. Les variables de contrôle incluent différents instruments de politique de l'emploi susceptibles de modifier le niveau des taux de chômage d'équilibre ou d'interagir avec les réformes du marché des biens. En effet, certaines politiques de l'emploi paraissent complémentaires de réformes sur le marché des biens. Les résultats obtenus sont cohérents avec le modèle de négociation et compétition imparfaite de Blanchard et Giavazzi (2003). Ils suggèrent que des règlementations restrictives se seraient traduites par des effets défavorables importants sur l'emploi dans les pays où aucune réforme significative sur le marché des biens n'a été mise en œuvre. Ces effets défavorables auraient été renforcés par des institutions conférant un fort pouvoir de négociation aux insiders, accréditant l'idée selon laquelle la constitution de rente de situation sur le marché du travail pèse sur l'emploi. En termes de politique économique, cet article suggère que des gains significatifs quant au niveau de l'emploi peuvent être attendus d'une dérèglementation des marchés des biens dans les pays exagérément restrictifs dans ce domaine. Ces gains seraient d'autant plus élevés que les rigidités sur le marché du travail sont importantes.

Classification JEL : J38, K20, L43

Mot clés : Réglementation du marché des biens et services, politique de l'emploi, fonctionnement du marché du travail, complémentarité des politiques économiques

\section{Copyright OECD, 2005}

Applications for permission to reproduce or translate all, or part of, this material should be made to: Head of Publications Service, OECD, 2 rue André-Pascal, 75775 Paris Cedex 16, France. 


\section{TABLE OF CONTENTS}

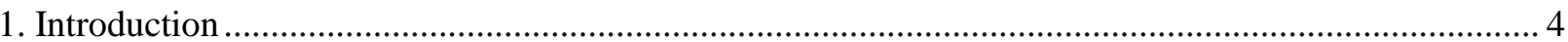

2. The effects of product and labour market policies on employment: what do we know? ..................... 6

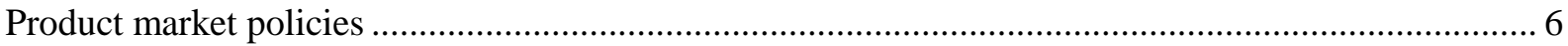

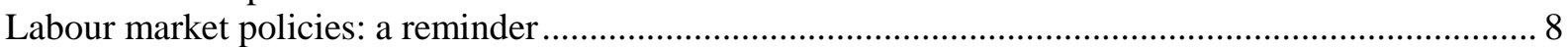

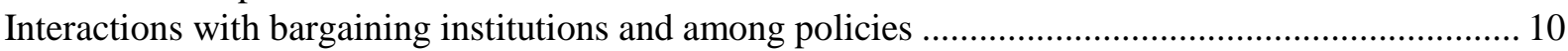

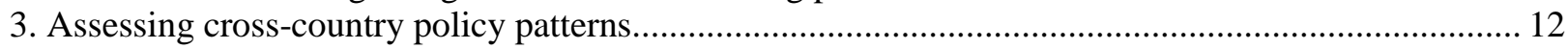

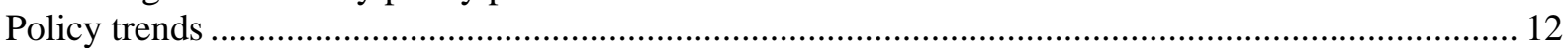

The relationship between labour and product market policies ........................................................ 17

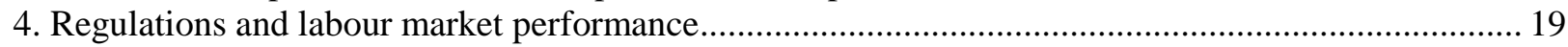

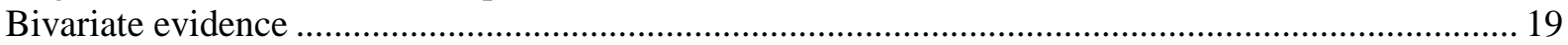

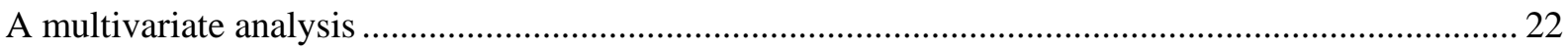

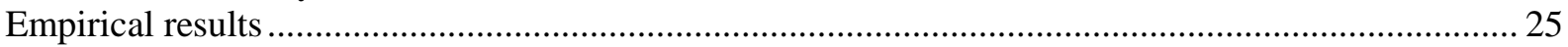

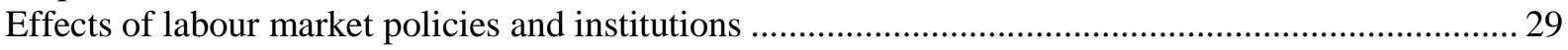

Product market regulation and its interaction with labour market policies .......................................... 31

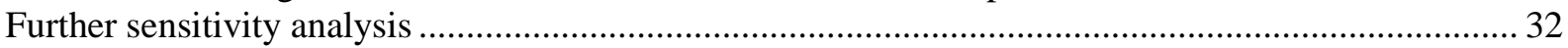

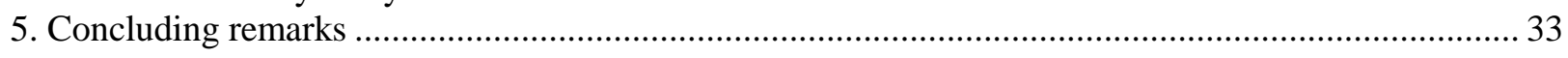

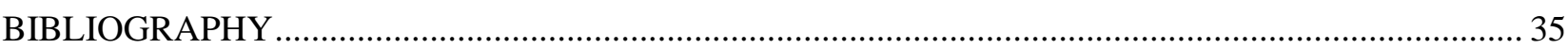




\title{
PRODUCT MARKET REFORMS AND EMPLOYMENT IN OECD COUNTRIES ${ }^{1}$
}

\author{
Giuseppe Nicoletti and Stefano Scarpetta \\ (OECD and World Bank)
}

\section{Introduction}

1. Is product market competition conducive to higher employment rates? Are policies aimed at easing entry and reducing government controls in competitive markets (in short "deregulation") an alternative or a complement to labour market reforms that may be politically difficult to implement? Recent research has set out a variety of channels through which employment may be affected by the degree of product market competition (Krueger and Pischke, 1997; Nickell, 1999; Pissarides, 2001a; Spector, 2002; Blanchard and Giavazzi, 2003). Most studies point to the potential for competitive pressures to increase employment, at least in the long run. But the size of the expected employment effects has been related to both the nature of the increase in competition and the features of the labour market. For instance, some authors have distinguished the employment effects of new market entry from those of a mere increase in rivalry among incumbents (Blanchard and Giavazzi, 2003). Others have argued that the size of the effects depends on the wage-setting mechanisms and the bargaining power of workers (Amable and Gatti, 2001; Ebell and Haefke, 2003). These studies have stressed two kinds of interactions between product and labour market policies and institutions: the political one that arises when reforms in one area hinder or facilitate reforms in the other area; and an interaction affecting outcomes, which arises when the employment effects of reforms in one area are diminished or magnified by the stance of policies or institutions prevailing in the other area. Of course, the two areas are related to the extent that political complementarity (substitutability) may magnify (reduce) the effects of policies implemented in one of them.

2. There was, however, surprisingly little empirical work aimed at assessing the empirical relevance of these theoretical insights. ${ }^{2}$ In part, empirical analysis has been made difficult by the lack of adequate proxies expressing the intensity of competition, especially in a cross-country context. Traditional proxies, such as measures of market power, are not widely available and are often found to be endogenous to labour market outcomes. Moreover, they are often irrelevant for policy. ${ }^{3}$ To overcome these problems, Boeri et al., (2000) and Nicoletti et al. (2001) have explored the aggregate long-run effects of product market

1. The authors thank participants in the Banco de Portugal Conference on "Labour Market Institutions and Economic Outcomes" (3-4 June 2001, Cascais), the CEPR/ECB Labour Market Workshop on "What Helps or Hinders Labour Market Adjustments in Europe" (Frankfurt am Main, 28-29 June 2004), the FRDB/IGIER workshop on "Frontiers of Labour Economics" at Bocconi University (Milan, 20 January 2005), the Lunchtime Seminar Series at the Department of Industry and Trade (London, 9 March 2005), the DEFAP Seminar Series at Università Cattolica (Milan, 24 June 2005) and an OECD Economics Department seminar for useful comments on previous versions of this paper. The views expressed in this paper are our own and should not be held to represent those of the OECD, the World Bank or their Member governments.

2. The few studies include Nicoletti et al., (2001), Boeri et al., (2001), Bertrand and Kamarz (2002), Kugler and Pica (2003) and Griffith and Harrison (2004).

3. For instance, mark-up estimates or industry concentration indices are generally useless for both competition authorities, which operate at the level of micro-markets, and policy-makers, who need to identify the policies that curb overall product market competition. 
regulation on employment using a set of proxies that focus on some of the policy determinants of product market competition. ${ }^{4}$ Combining these policy indicators with measures of labour market regulations and institutions, they find cross-country evidence suggestive of a positive impact. However, the main limitation of their analysis is that their proxies for competition only have a cross-country dimension and, therefore, provide only a partial match to the available time-series information concerning developments in labour market policies and outcomes. Moreover, no attempt was made to explore the interaction between policies in the labour and product markets.

3. This paper innovates in two ways. First, we look at the effects of product market reform on employment in 20 OECD countries over the 1980-2002 period. To this end, we use a proxy that follows developments in the regulation of seven non-manufacturing industries over the past two decades, an indicator that has been recently used by Alesina et al., (2005) and Nicoletti and Scarpetta (2003) to study the effect of regulation on investment and multifactor productivity, respectively. ${ }^{5}$ There are good reasons to focus on non-manufacturing regulation. This is the area of the economy where regulations vary the most over the sample period and across countries. Moreover, the non-manufacturing sector accounts for a large share of total employment in all OECD countries, and is the sector that has generated most of the variation in employment in OECD countries over the past two decades. Finally, non-manufacturing regulation has an important impact on costs elsewhere in the economy through input-output linkages. Anticipating the results, we find that deregulation has raised employment rates significantly in countries where nonmanufacturing reforms were extensive.

4. Second, we make a first attempt at exploring empirically the degree of complementarity between policies in the labour and product markets. We estimate the impact of regulatory reform on long-run employment performance jointly with the effect of labour market regulations and institutions, such as employment protection, bargaining arrangements and social policies, which are commonly considered to be important determinants of employment equilibrium levels (see, e.g., Layard and Nickell, 1998). We find suggestive evidence that policies in the two markets are political complements, but we do not look further at the source of this complementarity. Instead, we focus on their complementarity in driving employment outcomes. Again, anticipating the results, we find that restrictive product market regulations are particularly detrimental for employment in countries where policies provide a relatively high bargaining power to insiders. This gives some support to the insights of recent simulation studies exploring productlabour market interactions (Ebell and Haefke, 2004). The results also suggest that, in rigid labour markets, "right to manage" bargaining prevails and rent sharing has an "allocative" role, lowering employment by increasing the wage-productivity gap. Product market deregulation increases employment both directly and indirectly, by reducing the available rents and this gap. Thus, where insider power is strong, the employment effects of deregulation are stronger than in countries with more liberal labour markets.

5. The plan of the paper is as follows. Section 2 briefly reviews the theoretical and empirical evidence concerning the effects of regulations in product and labour markets on employment, exploring also the possible interactions between policies in the two markets. Section 3 describes policy approaches in the subset of OECD countries covered by the analysis and looks at prima facie evidence of complementarity between some of these policies. The focus is on employment protection, tax wedges, unemployment benefits and regulation in the non-manufacturing sector. Section 4 presents panel data estimates of the effects of product and labour market policies on the ratio of employment to working age population. Section 5 concludes.

4. These proxies attempt to measure to what extent product market policies are keen to competition, in particular areas and overall. They are based on a large set of information on regulatory provisions in OECD countries (Nicoletti et al., 1999).

5. This indicator is described in detail in the Annex and in Conway and Nicoletti (2006). 


\section{The effects of product and labour market policies on employment: what do we know?}

6. Government policies are likely to affect significantly (in intended or unintended ways) the functioning of labour markets. Here, we focus on those product market policies that can have adverse effects on employment by affecting the rents earned by firms and workers. We look at $i$ ) regulations restricting firms' decisions over entry, output and prices; and ii) public ownership and control of business enterprises. For simplicity, we term "deregulation" the policies aimed at easing unnecessarily restrictive regulations and government controls. We also control for a subset of labour market policies whose potential effects on employment are widely recognised. These include i) tax policies that create a wedge between the cost of labour and the take-home pay of workers; ii) unemployment benefit schemes; iii) employment protection legislation disciplining temporary and permanent work contracts; and $i v$ ) public employment policies. Finally, in keeping with a vast body of research, we also consider the effects of bargaining systems and unionisation. Conceptually, these policies and institutions may all have both direct and indirect effects on equilibrium employment, either in isolation or interacting among them and with other public policies. A reminder of the main channels follows.

\section{Product market policies}

7. Regulation generally reflects public interest concerns, with the main rationales being natural monopoly conditions, externalities, asymmetric information and other types of market failures. However, regulatory frameworks may be flawed by several (possibly concurring) factors. First, some regulations may drift away from their original public interest aims, resulting in the protection of special interest groups. Second, regulations (and their implementation) sometimes involve costs that exceed their expected benefits, leading to so-called "government failure". ${ }^{6}$ Third, technical progress, the evolution of demand and progress in regulatory techniques can make the design of regulations obsolete (OECD, 2001).

8. In (otherwise) competitive markets, regulations that are unnecessarily restrictive of market mechanisms may curb competition by limiting new entry and rivalry among firms. ${ }^{7}$ Competition may also be affected by state control over business enterprises, which may have stronger incentives to engage in anti-competitive behaviour than their private counterparts (Sappington and Sidak, 2003). State ownership generally shelters from the market discipline exercised by private shareholders as well as from the threat of takeover or bankruptcy. These distortions are often linked to the presence of soft budget constraints, due to the availability of state aid and debt guarantees (Kornai et al., 2003).

9. Regulations that curb competition may have several consequences for labour demand both at the firm level and in the aggregate. ${ }^{8}$ At the firm level, the presence of market power tends to reduce the wage elasticity of demand and shift inwards the labour demand schedule (Hicks, 1935). In addition, product

6. Government failure occurs when good intentioned policies have effects that are costlier than the market failures that they aim to correct. Reasons for government failure include the pursuit of self-interest by politicians or civil servants in charge of implementing policies; electoral pressures that distort the application of policies; regulatory capture by industry interests; unforeseen side effects of policies (such as disincentives, spillovers or externalities); asymmetries of information that make the implementation of policies difficult; etc. On the balance of costs and benefits of regulation, see Office of Management and Budget (1998).

7. Ill-designed regulations (such as flawed access regulations to networks) may cause similar inefficiencies in imperfectly competitive markets by reducing or eliminating actual or potential competition.

8. In addition, entry restrictions may constrain the supply of a particular type of capital, entrepreneurial ability (Krueger and Pischke, 1997). 
market rents prompt employees to ask for wage premia, especially if they are unionised. ${ }^{9}$ Ceteris paribus, this induces firms to choose capital-labour ratios higher than in a competitive situation, causing lower employment and productive inefficiencies. On the other hand, political meddling and the lack of market discipline may also encourage managers of public enterprises to use inputs inefficiently by employing excess labour. Recent research has stressed two main ways in which regulations that curb competition can also affect aggregate employment as well:

- First, such regulations create fixed costs of entry that generate rents, reducing the number of competing firms and output in the long-run. Thus, when deregulation leads to a decrease in entry costs, it has a positive effect on equilibrium employment, because the number of firms expands, rents decrease and output levels increase. ${ }^{10}$ This implication is common to imperfect competition models in which labour markets are characterised by either bargaining (Spector, 2002; Blanchard and Giavazzi, 2003) or Mortensen-Pissarides job-matching mechanisms (Pissarides, 2001a; Ebell and Haefke, 2003).

- Second, regulations can lower the intensity of competition between existing firms. Here, the results of deregulation depend on model specifications. Using a simple two-period model in which unemployment arises from the bargaining power of workers, Blanchard and Giavazzi (2003) find no effect on equilibrium unemployment. However, Ebell and Haefke (2003) find effects symmetric to those of a reduction in entry costs in a fully dynamic setting in which unemployment arises from a job-matching framework. Deregulation reduces long-run unemployment because labour-market tightness increases under both deregulation scenarios. The size of the latter effects, however, is inversely related to the average survival rate of firms (because as survival rates decrease, entry costs need to be amortised more quickly).

10. More generally, the size of the employment effects will depend also on the features of labour market institutions (e.g., degree of unionisation and centralisation of bargaining mechanisms) (Nickell, 1999). For instance, Ebell and Haefke (2004) show that the effects of deregulation on employment are larger when bargaining mechanisms are endogenised, and depend on the amount of rents to be earned by workers and firms. Amable and Gatti (2001) show that in an efficiency wage model deregulation may have little effect on employment if it leads to increases in the reservation wage of workers related to the increased risk of lay-offs in bad states of the world.

11. In sum, while there is a strong presumption that easing anticompetitive regulations may lead to employment gains (at least in the medium to long-run), whether this effect can contribute to explain observed cross-country differences in labour utilisation has to be checked empirically. However, only a handful of studies have done so to date. Controlling for labour market policies and institutions, Boeri et al., (2000) and Nicoletti et al., (2001) find that various measures of product market regulation are negatively related to employment rates in a panel of OECD countries over the past two decades. Controlling for a few other variables, Messina (2003) relates a measure of entry costs to the overall employment rate as well as the share of employment in services over a similar panel of countries, finding negative effects in both cases. He interprets this evidence as suggesting that entry costs also have the effect of slowing down structural adjustment towards the service sector. Pissarides (2001a) finds a negative correlation between a measure of start-up costs and employment rates across a smaller subset of OECD countries. Finally, Kugler and Pica (2003) find that strict product market regulations are likely to lessen the effects of labour market

9. Depending on the degree of market regulation and the ownership structure of the firm, these premia can take pecuniary or non-pecuniary forms. See Jean and Nicoletti (2004).

10. The shift in labour demand tends to raise wages while stronger competitive pressures tend to lower prices, raising both real wages and labour supply. Thus, in the new equilibrium both employment and real wages may increase. 
reforms on employment, focusing on a micro data set concerning Italy over the 1990s. None of these studies has explicitly looked at the employment effects of changes in regulation over time in an estimation framework accounting for other potential policy and institutional influences and allowing for interactions among policies in labour and product markets.

\section{Labour market policies: a reminder}

Tax wedges

12. Labour income taxes and social contributions that drive an excessively large wedge between the cost of labour and the take-home pay of workers can increase long-run unemployment rates, if there is not full pass through of the taxes on bargained wages. Moreover, high marginal tax wedges have a direct impact on the supply of labour, reducing hours worked and labour force participation of marginal groups of workers (e.g., youth, women, unskilled and older workers). These supply effects act through changes in the relative prices of leisure, non-market activities (home production or the informal economy) and market work (Nickell, 2004; Davis and Henrekson, 2004). Tax wedges can also affect labour demand through various channels. For instance, they can alter the composition of labour demand in ways that amplify negative substitution effects on hours and employment (Davis and Henrekson, 2004), notably by shifting activities that are intensive in low-skilled work out of the market sector. As reviewed by Koskela (2001), labour market imperfections (e.g., non-decentralised bargaining arrangements) also cause changes in tax wedges to affect labour costs and equilibrium employment. Perhaps the largest negative effects on labour demand arise from the interaction of high tax wedges with binding wage floors (resulting from either contractual or statutory minimum wages). The existence of such floors can exacerbate the negative effect of high tax wedges on the employment opportunities of the low-skilled, because they further limit the possibility for tax-shifting at the low end of the pay scale, effectively increasing the minimum cost of labour and depressing labour demand for these groups of workers.

13. There is growing empirical evidence suggesting that high tax wedges are an important determinant of cross-country differences in the utilisation of labour. Using a simple simulation model of labour-leisure choice, Prescott (2004) shows that different tax wedges might explain a large part of differences in hours worked across G7 countries. In a survey of recent econometric work in this area, Nickell (2004) reports several significantly negative estimates of the long-run impact of tax wedges on employment rates. Studies that control also for the influence of other labour market policies and institutions generally find that a 10 percentage point increase in the tax wedge may lead to a 1 to 3 percentage point fall in the employment rate (Scarpetta, 1996; Elmeskov et al., 1998; Layard and Nickell, 1998; Nickell et al., 2003). ${ }^{11}$

\section{Unemployment insurance}

14. The combination of high unemployment benefits relative to the previous wage (the so-called income replacement ratio) with a long duration of entitlements is likely to have detrimental effects on unemployment (Mortensen and Pissarides, 1999; Layard and Nickell, 1998; Blanchard, 2000). Notably, high replacement ratios tend to insulate employed workers from overall labour market conditions by raising the value of their outside option, thereby increasing their bargaining power at the expense of outsiders. With higher bargained wages, equilibrium unemployment rises. Moreover, high and durable benefits reduce the incentives for the unemployed to search for work and fill vacancies. This lengthens unemployment spells, thereby increasing the persistence of unemployment and, in equilibrium, the unemployment rate. However, the effects of benefit systems on employment rates are more uncertain,

11. Daveri and Tabellini (2000) estimate a -5.5 percentage point effect, but they do not control for the effects of other labour market policies. 
because labour supply may also be affected in various ways. On the one hand, they tend to increase it by making labour market participation more attractive, on the other hand, they tend to decrease it through "discouraged worker" effects due to long unemployment spells.

15. Cross-country evidence of negative effects of generous benefit schemes on unemployment is abundant (OECD, 1994a,b; Scarpetta, 1996; Nickell, 1997). There is also evidence that too generous schemes tend to curb employment rates (Elmeskov et al., 1998; OECD, 2004). However, these negative effects can be reduced by strengthening work-availability and willingness-to-work requirements. Moreover, there appears to be a policy trade off between unemployment insurance and employment protection provisions (Boeri et al., 2003), suggesting the need to account for both these policies in econometric estimations (see below).

\section{Employment protection legislation}

16. In theory, "employment protection" legislations (EPL), if appropriately designed, could serve several purpose, from setting rules against unfair behaviour of employers, to providing insurance against job loss and internalising the social costs of dismissals (Lindbeck and Snower, 1988; Pissarides, 2001b; Blanchard and Tirole, 2004). In practice, however, they may affect the equilibrium level of employment in conflicting ways. By reinforcing job security and long-lasting employment relationships, EPL may enhance productivity performance, as workers will be more willing to co-operate with employers in the development of the production process (Akerlof, 1984) and employers are encouraged to provide training to workers. A better skilled workforce may also increase internal flexibility and thus lead to a better functioning of production activity (Piore, 1986). However, if EPL is very strict, as in many European countries, firms may become more cautious about adjusting their workforce, with the ultimate effect of reducing labour turnover, e.g., movements from employment to unemployment and from unemployment back to employment (Bertola, 1992). In addition, if hiring and firing costs are not transferred into lower wages, total labour costs for the firms increase and this may lead to a lower level of employment, other things being equal. Thus, EPL provisions that make it difficult for employers to predict these costs (and account for them at the wage-setting stage) are likely to be particularly detrimental for employment (OECD, 2004). Put differently, the effective coverage or implementation of standard employment protection provisions influences the overall strictness of EPL regulations (Bertola et al., 2000). ${ }^{12}$

17. Empirical evidence on the impact of employment protection legislation is mixed, not least because of the lack of suitable data on the enforcement and the evolution of regulations over time. There is consistent empirical evidence that, under strict EPL provisions, the unemployment pool is more stagnant, with fewer people being laid off, but also fewer unemployed people getting a new job (Bentolila and Bertola, 1990; and Layard and Nickell, 1998). However, the effects on employment turnover are less clear cut. For instance, Bertola and Rogerson (1997) and Boeri (1999) found similar job creation and job destruction rates across countries with different EPL regimes but lower unemployment flows in rigid labour markets. ${ }^{13}$ By reducing unemployment turnover, strict EPL is also found to slow down the labour market adjustment after an exogenous shock (Jackman et al., 1996; Scarpetta, 1996).

18. While there is some evidence on the impact of EPL on labour market flows, the evidence concerning the equilibrium level of employment or unemployment is even less clear cut. Boeri et al.,

12. For instance, in some countries, the judicial system appears to have interpreted legislation more strictly than was intended by the law and this has created a large uncertainty over the actual costs of EPL.

13. As stressed in Boeri (1999) and OECD (1999b), a possible explanation is that strict EPL may foster job-to-job shifts rather than overall employment turnover because employers and workers will seek direct shifts from one job to another without intervening unemployment spells, in order to avoid the associated dismissal and search costs. 
(2000), Nickell (1997) and Heckman and Pagès (2000) find a detrimental effect of strict EPL on the employment rate, ${ }^{14}$ but some studies suggest that this may differ across categories of workers (OECD, 1999a; Heckman and Pagès, 2000). As to the overall impact of EPL on unemployment, part of the disagreement stems from the use of different models, data sets and proxies for EPL. ${ }^{15}$ Differences in results also depend on the range of other policy variables and potential interactions between policies and institutions that are taken into account (see below).

\section{Public employment}

19. Research on the overall employment effects of public employment programmes has not been extensive. ${ }^{16}$ Some studies suggest that public employment is likely to crowd out private employment by creating wage pressures, thereby increasing the equilibrium unemployment rate (Holmlund and Linden, 1993; Calmfors and Lang, 1995). This is especially the case if public sector unionisation is relatively high (Holmlund, 1997). Wage (and non-wage) premia in the public sector can also generate "wait unemployment" phenomena, in which unemployed workers reduce job search efforts, queuing for a job in the public sector. More specifically, Algan et al., (2002) show that crowding out effects increase with the substitutability of the services produced by workers in the public and business sectors. For instance, public and private health services are likely to be highly substitutable, while public employees that provide pure public goods are likely to be much less substitutable. By contrast, public employment that substitutes for home production (e.g., child care or long-term health care) may even be complementary to business sector employment. Other indirect crowding out channels, for example through increased tax or debt pressures generated by extensive public employment programmes, have received little attention, though they may be important.

20. Empirical estimates tend to confirm the crowding out effects of public employment. For instance, Malley and Moutos (2001) and Boeri et al., (2000) find significant crowding out effects on private employment based on single country time-series and cross-country time-series data sets, respectively. The thorough study by Algan et al., (2002), which controls for potential endogeneity between private employment outcomes and levels of public employment, also points to a negative effect of public employment on equilibrium unemployment in a cross-section time-series analysis of a large sample of OECD countries over the past four decades. The authors also find a slight negative effect on labour force participation. All in all, these effects significantly contribute to explain differences in business employment rates among OECD countries. However, aside from the endogeneity issue, precise estimates of these crowding out (or crowding in) effects may be hard to obtain also due to the intrinsic limitations of the public employment data, which rarely allow for sufficient breakdown into activities that have different degrees of substitutability with business sector employment.

\section{Interactions with bargaining institutions and among policies}

21. Labour market outcomes may also be affected by the interaction between policies and labour market institutions. These interactions have been analysed in the empirical literature, with a focus on the

14. Layard and Nickell (1998) indicate that this may be partially due to the low participation rates in Southern European countries, which also have strict EPL. However, participation rates may be low, especially amongst the youth, precisely because employment prospects are lower the stricter the EPL system.

15. Heckman and Pagès (2000) find no effect focusing on Latin American countries, while Scarpetta (1996), Elmeskov et al., (1998) and Nickell et al., (2001) find a negative and significant effect in OECD countries over long time periods; and OECD (1999a) does not find a statistically significant effect on a shorter time period. However, disagreement persists even amongst papers using the same proxy.

16. A good summary of theory and empirics is provided in Algan et al., (2002), who also present new results based on cross-country data. 
relationship between EPL and bargaining arrangements. Bertola and Rogerson (1997) suggest that higher turnover costs due to more stringent EPL are associated with higher unemployment in countries with industry-level - "intermediate" according to the Calmfors and Driffil (1988) taxonomy - bargaining systems, where wages do not fully adjust to labour market slack. ${ }^{17}$ This suggestion finds empirical support in the studies of Elmeskov et al., (1998), OECD (2004), Boeri et al., (2000) and Nicoletti et al., (2001), where the negative effects of EPL are stronger in countries having intermediate systems. Interactions among labour market policies have focused on EPL and unemployment insurance. Buti et al., (1998) point out that stringent EPL may act as a substitute for unemployment insurance benefits. Under this hypothesis, countries might opt for either generous unemployment benefits with lax EPL or the reverse. ${ }^{18}$ They argue that a combination of very generous benefits with strict EPL would lead to higher structural unemployment. However, the authors use simple bivariate correlation in their analysis, and Elmeskov et al., (1998) found no significant evidence of this interaction in an econometric analysis of the determinants of structural unemployment for a large sample of OECD countries.

22. Recent research has also focused on the potential interactions between labour and product market regulations. This has concerned both the political economy of reforms and the effects of regulation or deregulation on labour market outcomes. Several authors have focused on "political complementarity". For instance, liberalisation can pave the way for labour market reforms by reducing product market rents and, therefore, incentives to fight for capturing them (Blanchard and Giavazzi, 2003) or securing them by increasing insider power (Saint Paul, 1996). Similarly, free entry makes it harder for firms to bear the costs of EPL and may reduce the incentives for insiders to protect jobs, due to possible positive effects of competition on employment opportunities (Koeniger and Vindigni, 2004). Alternatively, labour market reform can make product market reform more attractive for workers, because the positive real wage effects of deregulation may be stronger when insider power is modest (Spector, 2003). Empirical evidence points to a close and persistent relationship between employment protection and product market regulations across countries (Nicoletti et al., 1999; Conway et al., 2005). We show below that there is also a strong cross-country co-variation between product market regulation and a wider set of labour market policies. Moreover, there is suggestive evidence that product market reforms often preceded labour market reforms in a wide sample of OECD countries over the past two decades (Brandt et al., 2005). While these bivariate correlations provide some support to the idea that the two types of regulations are political complements, more research is needed to investigate directions of causality and make sure that bivariate correlations are not caused by a third factor, such as changes in political majorities or cultural influences, which could drive reforms in both areas.

23. Less research has been devoted at exploring whether reforms in one of the two areas may boost or curb employment gains to be obtained from reforms in the other. What should be expected here? Schematically, one can distinguish two situations. If labour market policies and institutions ensure flexibility and low bargaining power, wages will tend to align on productivity whatever the level of regulation and the associated product market rents. Conversely, if labour market policies and institutions enhance rigidities and bargaining power, wages will tend to be further above productivity the more regulations inhibit competition and the larger are the associated rents. Blanchard and Giavazzi (2003) note that the implications of product market reforms for employment depend on the nature of the bargaining system. With efficient bargaining (in which firms and unions set simultaneously wages and employment), rent appropriation by workers has purely distributive effects, while in "right to manage" settings (where unions set the wages and firms adjust employment accordingly) this appropriation has allocative effects as well, resulting in lower employment outcomes. In this case, we would expect long-run employment gains

17. The underlying assumption is that in centralised bargaining systems unions internalise the effects of wage claims on employment levels.

18. Boeri et al., (2003) document and formalize this policy complementarity in a political economy context. 
from product market deregulation to be larger in rigid labour markets, where they would result from both lower rents and a smaller wage-productivity gap, than in flexible ones, where only gains from the first channel would be obtained. Conversely, we would expect the long-run employment gains from labour market deregulation to be largely independent of the degree of product market regulation, since they would tend to close the gap between wages and productivity by the same amount in markets with high and low rents. These conjectures need to be verified empirically because, as mentioned above, they depend crucially on the nature of the underlying bargaining system. However, empirical analysis looking at the joint effects of labour and product market policies on employment has been lacking to date. The next sections of this paper provide an initial attempt in this direction.

\section{Assessing cross-country policy patterns}

24. Information on labour and product market regulations consists of a multitude of sector-specific or general-purpose provisions. Although, in principle, cross-country comparisons of individual regulations are possible, the analysis of the linkages between policies and labour market performance requires some aggregation. We use four main policy indicators to measure differences in policy approaches across countries and over time. On the labour market side, we summarize various sources of labour income taxation by the tax wedge on a typical production worker; unemployment benefit systems by a synthetic measure of the share of income that is replaced upon job loss; and employment protection by a measure aggregating various dimensions of legislation and compliance requirements for firms hiring temporary and/or permanent workers. On the product market side, we use an indicator of regulation that covers state controls and barriers to entry in the competitive markets of a subset of energy and service industries. Both the labour market and product market indicators follow policy developments in our sample of OECD countries over the past two decades and can be used, therefore, to gauge the extent and the pace of reforms implemented in the two markets.

25. We consider that the indicator of regulation in non-manufacturing is a good proxy for assessing the effects of product market reform on employment for several reasons. First, non-manufacturing is the sector where restrictive regulations and state controls were generally most widespread and where the widest-ranging reforms took place. Second, this sector accounts for an increasingly large share in activity and total employment. Third, non-manufacturing products represent a significant intermediate input in manufacturing production. Thus, changes in regulation leading to stronger competitive pressures are likely to reduce rents in this sector more significantly than in other industries and the corresponding decrease in the cost of non-manufacturing inputs should propagate widely throughout the economy. If the theoretical insights discussed in the previous section are correct, this should stimulate the expansion of aggregate output and employment. ${ }^{19}$ The rest of this section describes trends in labour and product market policies of OECD countries and highlights the apparent complementarity between policies in the two markets.

\section{Policy trends}

\section{Tax wedges and unemployment insurance}

26. Figure 1 shows the evolution of tax wedges and gross replacement ratios over the sample period in some countries (or groups or countries) covered in our study. Tax wedges are defined as the share in total labour costs of the difference between the costs of labour and the take-home pay of a married production worker with two children and earning the average wage (average of three family situations depending on spouse's earnings). This measure includes income taxes and both employer's and employee's social security contributions. Gross replacement rates are a summary measure of the fraction of

19. Evidence that productivity gains due to regulatory reforms in non-manufacturing affect aggregate productivity growth through input-output linkages is provided by Faini et al., (2004) and OECD (2005). 
income replaced by unemployment benefits over a five years period for three family types and two earnings levels. ${ }^{20}$

\section{[Figure 1. Tax wedges ${ }^{1}$ and replacement rates $^{2]}$}

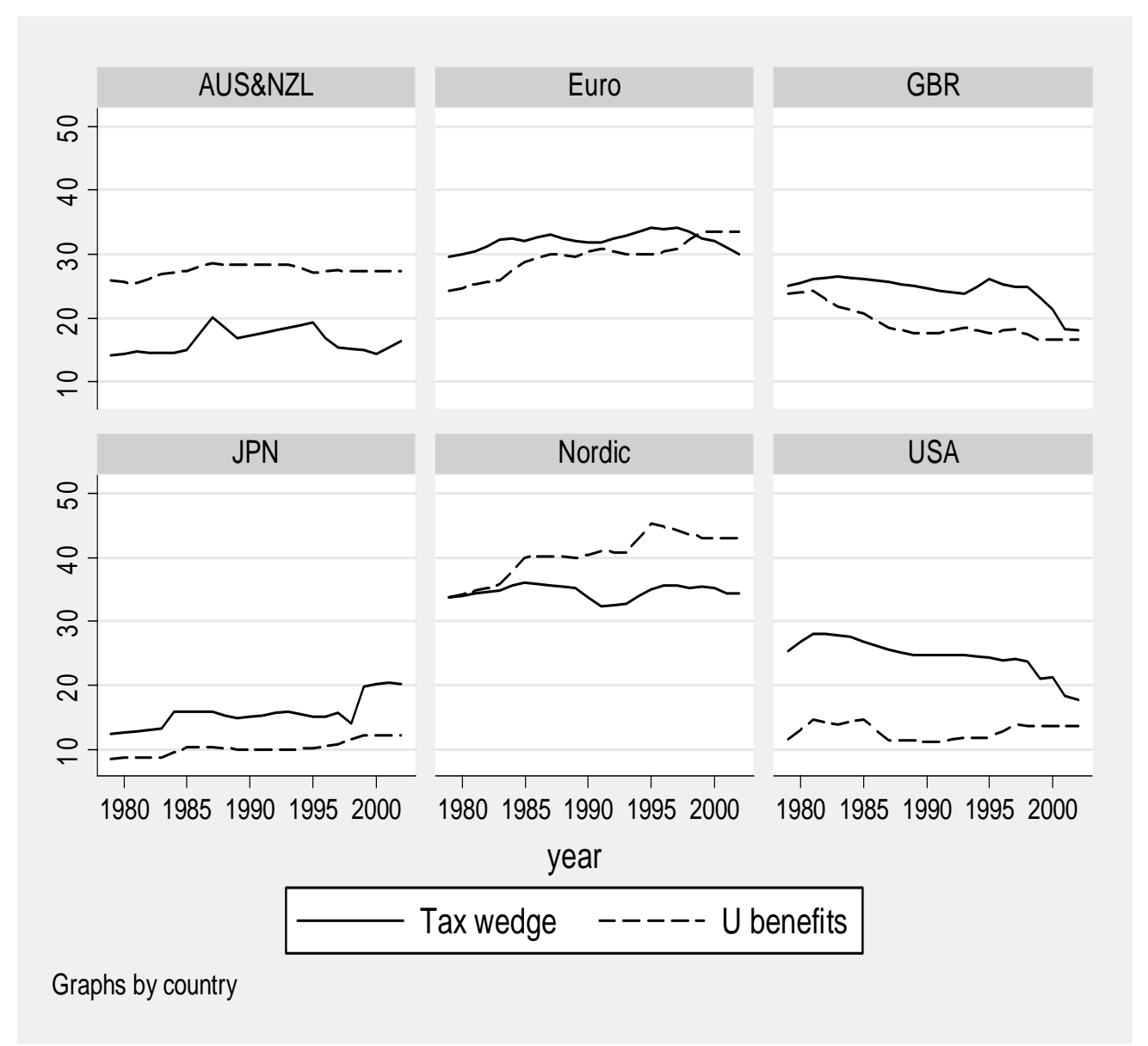

1. Total tax wedge for a worker earning the average production wage, including employer's and employee's social security contributions. Couple with two children, average of three family situations depending on spouse's earnings.

2. Average of gross replacement rates (of earnings at $67 \%$ and $100 \%$ of the average production wage) for three family types during a five-year period.

Euro $=$ Euro area countries less Luxembourg.

Nordic $=$ Denmark, Sweden, Norway

Source: OECD

27. In several European countries, tax wedges on average earned income have traditionally been relatively high (notably in France, Germany, Belgium, Italy, Sweden and Finland). In a few of them (Norway, Ireland the Netherlands and, to a lesser extent, Italy) tax reforms have significantly reduced average tax wedges recently, accounting for the slight decline in the average tax wedges of the Euro area and the Nordic countries. Tax wedges tend to be lower in North America, Japan, Australia and New

20. Both tax wedges and gross replacement rates are computed by the OECD. The net replacement rate would be a preferable indicator, but unfortunately it is currently available only for a few years. For a discussion of the different definitions of replacement rates, see Martin (1996). 
Zealand. Gross replacement rates are also relatively high in many European countries - particularly so in Denmark, Switzerland, Sweden and the Netherlands. Over the 1990s, OECD countries were generally reluctant to lower benefits and/or shorten benefit periods. Indeed, the most substantial changes often went in the opposite direction, with gross replacement rates increasing significantly in countries such as Portugal, Switzerland, Austria and the Netherlands. This explains the upward drift in average replacement rates in both the Euro area and Nordic countries. On the other hand, a few countries (Denmark, Ireland, the Netherlands and the United Kingdom) also strengthened work-availability and willingness-to-work requirements, and their enforcement, making continued benefit receipt after a certain period conditional on participation in so-called "active labour market policies" programmes or other "activation" measures.

\section{Employment protection}

28. The OECD indicator of EPL covers restrictions concerning workers on both permanent and temporary contracts. Individual dismissal protections for workers with permanent contracts include: procedural inconveniences that employers face when trying to dismiss a worker; notice and severance payments at different job tenures; and prevailing standards of and penalties for "unfair" dismissals. The indicator for temporary contracts covers, for both fixed-term contracts and contracts through temporary work agencies (TWA): the "objective" reasons under which they could be offered; the maximum number of successive renewals; and the maximum cumulated duration of the contract. Information on these aspects of employment protection has been collected by the OECD for the late 1980s, the late 1990s and 2002. The EPL indicator used in the econometric analysis below is time-varying, with the shifts in regime from the late 1980s to the early 2000s being defined on the basis of information about the timing of major EPL reforms (concerning both temporary and regular workers) in OECD countries. ${ }^{21}$ The indicator is described in detail in OECD (2004).

29. Figure 2 plots the summary indicators of EPL for permanent and temporary workers for the late 1980s and for 2002. In countries along the diagonal, the summary EPL indicator did not change over the period; in those above the diagonal, regulations became tighter; and in those below the diagonal, regulations were relaxed. Broadly speaking, there has been a tendency for a significant deregulation of temporary contracts, while only modest changes have been recorded for permanent contracts. Only Finland, Portugal and Spain have significantly eased regulation for permanent workers. In Finland both the delay to the start of notice and the notice period itself were reduced; and in Spain new permanent contracts were introduced with lower (albeit still high) severance payments. In other countries, changes were either minimal or in offsetting directions. ${ }^{22}$ In a number of countries temporary contracts are now easier to use than two decades ago. This was achieved in various ways:

- The range of situations for which fixed-term contracts can be offered has been widened in Japan, Germany, Italy, Belgium, the Netherlands, New Zealand and Sweden. In Spain, these contracts were liberalised in the late 1980s, and, following the dramatic increases in their use, some restrictions have been re-imposed recently. All restrictions on the types of work for which TWA employment is legal have been removed in Denmark and Sweden, while in Italy and Spain the previous complete ban on TWA employment has been lifted for certain types of work. Other relaxations on the range of jobs for which TWA are allowed have taken place in Germany, the Netherlands, Norway and Japan.

21. Due to lack of data, EPL policies have been assumed to be constant over the 1980-1989 period in empirical analysis.

22. For instance, the Netherlands eased restrictions on dismissals, widening exemptions from general dismissal law but increased the minimum notice period and decreased the maximum periods. 
- Restrictions on the maximum number of successive renewals have been eased for fixed term contracts in Germany, Italy, Belgium, the Netherlands and Sweden, and have been removed for TWA contracts in Denmark.

- The maximum cumulative duration for both kinds of (successive) temporary contracts has been lengthened in Germany, Belgium, the Netherlands and Portugal, while such easing has concerned fixed-term contracts only in Italy and Sweden, and TWA contracts only in Denmark.

30. Most of these policy changes were implemented before 1998, while more recent developments suggest that there is no clear direction of change in the area of employment protection. Only Italy and (to a lesser extent) Belgium further eased rules for temporary work and only Spain and (to a lesser extent) the Netherlands relaxed rules on permanent contracts. Changes in other EU countries partially reversed the earlier easing of temporary contracts and, in some instances, further tightened rules for permanent contracts (e.g., in France).

Figure 2. Indicators of the strictness of employment protection legislation, 1989-02

Panel A. Regular and temporary contracts

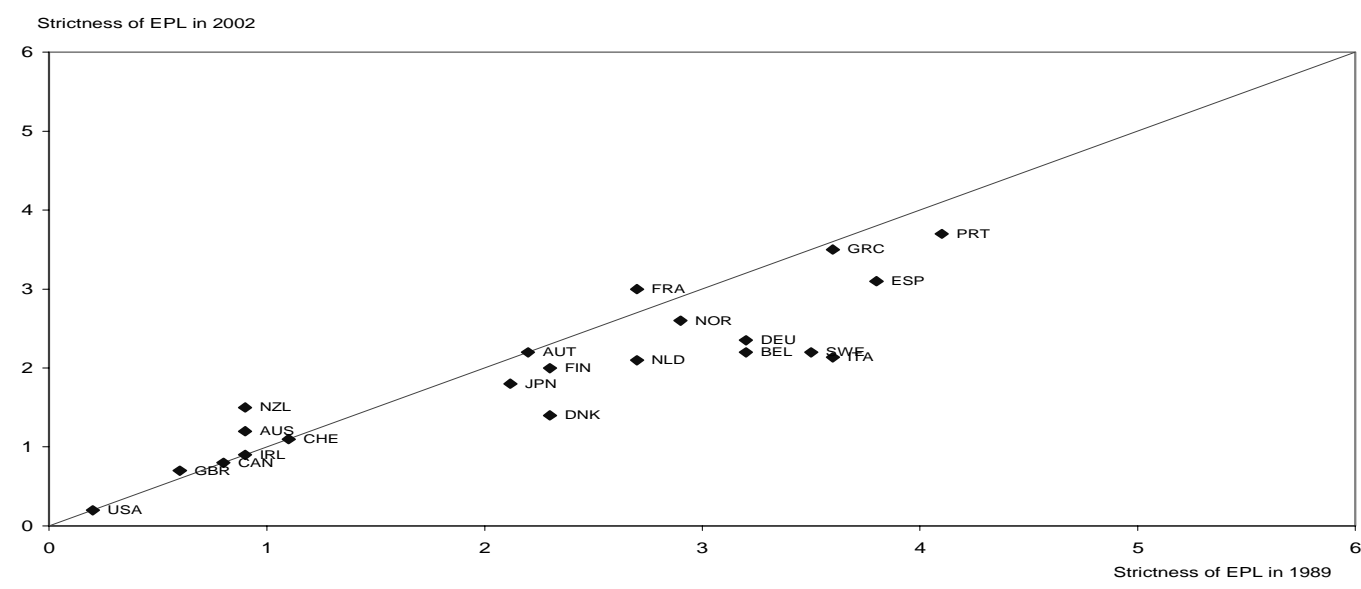

Panel B. Regular contracts

Panel C. Temporary contracts
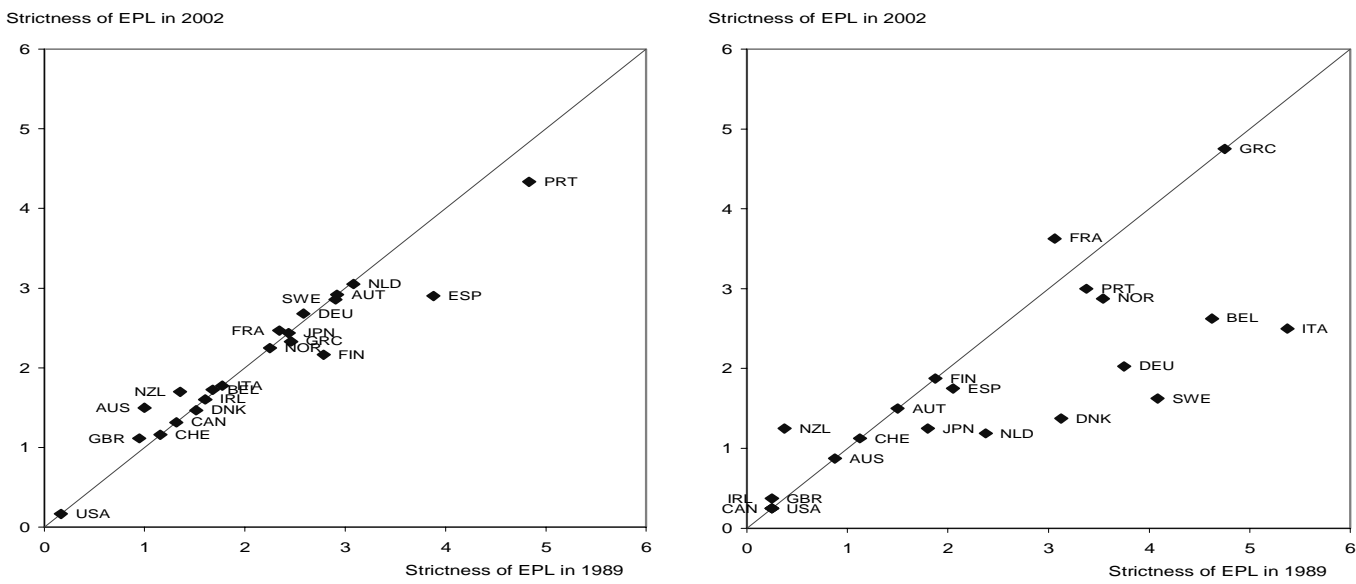

Note:

1. The indicator is the weighted sum of indicators referring to several aspects of employment protection legislation for regular contracts as well as for fixed-term and TWA contracts. The original indicators range from 0 (least restrictive) to 6 (most restrictive). 2. 1990 for New Zealand

Source: OECD (2004). 


\section{ECO/WKP(2005)59}

\section{Product markets}

31. Product market reform was analysed along three main axes: $i$ ) reduction in direct state control of economic activities - through privatisation or lesser interference in the decisions of business sector enterprises (e.g., lifting price controls); ii) easing of legal barriers to entrepreneurial activity - through liberalisation of access to markets; and iii) easing of barriers to entry related to market and/or industry structure (e.g., through structural separation of vertically-integrated network industries).

32. The data used in this paper cover regulations and market conditions in gas, electricity, post, telecoms (mobile and fixed services), passenger air transport, railways (passenger and freight services) and road freight over the 1980-2002 period. The coverage of regulatory areas varies across industries. Regulatory barriers to entry are reported for all industries; public ownership is reported in all industries except road freight; vertical integration is documented for gas, electricity and railways; market structure is documented for gas, telecommunications and railways; and price controls are reported for road freight. Countries were classified in each period along a 0-6 scale from least to most restrictive in each of these areas. Industry-specific time-series indicators of regulatory and market environment were created by simple average of the indicators for the areas covered in each industry. Finally, the aggregate time-series indicators used in empirical analysis were obtained by averaging over all industries in each country. ${ }^{23}$ Further details on this indicator can be found in the annex, while a full description of methods, sources, coding assumptions and the underlying industry-level indicator values is in Conway and Nicoletti (2006).

33. Using these summary indicators, three patterns of non-manufacturing regulation can be established for the countries included in the sample: ${ }^{24}$ common-law countries (excluding Ireland), characterised by relatively liberal regulatory policies in all industries; northern continental European countries (excluding France) and Japan, characterised by a mix of liberal and restrictive policies depending on the industry; and southern European countries (including France) and Ireland characterised by uniformly restrictive policies across industries. ${ }^{25}$ In both 1998 and 2002, the cross-country correlation between our summary indicator of regulation in non-manufacturing and the economy-wide indicator of Conway et al., (2005) was close to 70\%, suggesting that the former is a good proxy for the cross-country dispersion in the latter. In order to interpret these patterns appropriately, it should be reminded that only formal and explicit regulations have been taken into account, leaving out all other informal procedures through which the government or trade associations can influence economic behaviour as well as possible differences in enforcement.

34. Table 1 reports the product market reforms that are captured by our indicator. Over the past quarter century, reforms were deepest in the United Kingdom, New Zealand, the United States and Australia, while policies changed relatively little in Southern European countries, France and Switzerland. Again, three main reform profiles can be identified looking at the evolution of regulatory indicators: the United States, which began regulatory reform at the turn of the 1980s; the United Kingdom, New Zealand,

23. An alternative would have been to aggregate across industries using value added or employment weights. However, value added or employment data at this level of disaggregation are seldom available. More importantly, this would have under evaluated the reform drive in important industries, such as electricity or telecoms, which have a relatively low weight but are crucial inputs into overall economic activity.

24. These patterns result from performing a standard cluster analysis using the Ward method over the period averages of the indicators for the seven industries. The results do not change if 2002 is taken as the reference period.

25. Ireland falls among the restrictive countries because wide-ranging reforms in this country concerned mainly administrative simplification and openness to trade and FDI. Reforms in the non-manufacturing sector have been more limited and are relatively recent. 
Canada and Japan, which began reforming during the 1980s; and most other countries, which changed regulatory policies over the 1990s.

Table 1. Product market regulatory reform in selected OECD countries

\author{
Time-series regulatory indicators ${ }^{1}$ \\ (scale $0-6$ from the least to the most restrictive)
}

\begin{tabular}{|c|c|c|c|c|c|c|c|c|}
\hline & 1978 & 1982 & 1988 & 1993 & 1998 & 2002 & $\begin{array}{l}\% \text { change } \\
1978-2002\end{array}$ & $\begin{array}{l}\text { Coefficient of } \\
\text { variation }\end{array}$ \\
\hline Australia & 4.0 & 4.0 & 3.9 & 3.2 & 1.9 & 1.5 & -62.3 & 0.29 \\
\hline Austria & 5.2 & 5.0 & 4.7 & 4.2 & 3.9 & 2.5 & -52.8 & 0.18 \\
\hline Belgium & 5.5 & 5.5 & 5.3 & 4.6 & 3.4 & 2.3 & -58.7 & 0.23 \\
\hline Canada & 4.0 & 4.0 & 2.7 & 2.5 & 2.1 & 1.8 & -56.3 & 0.28 \\
\hline Denmark & 5.5 & 5.5 & 5.5 & 4.2 & 3.0 & 1.7 & -68.4 & 0.29 \\
\hline Finland & 5.4 & 5.4 & 4.8 & 4.2 & 2.7 & 2.5 & -54.7 & 0.28 \\
\hline France & 6.0 & 6.0 & 5.8 & 4.9 & 4.3 & 3.3 & -44.7 & 0.16 \\
\hline Germany & 5.2 & 5.2 & 5.1 & 4.2 & 2.8 & 1.7 & -67.4 & 0.29 \\
\hline Greece & 5.7 & 5.7 & 5.7 & 5.5 & 5.3 & 4.2 & -25.6 & 0.07 \\
\hline Ireland & 5.7 & 5.7 & 5.0 & 4.7 & 4.4 & 3.3 & -42.6 & 0.15 \\
\hline Italy & 5.8 & 5.8 & 5.8 & 5.3 & 4.7 & 2.7 & -54.2 & 0.18 \\
\hline Japan & 5.1 & 5.1 & 4.0 & 3.3 & 2.9 & 2.3 & -55.0 & 0.26 \\
\hline Netherlands & 5.7 & 5.7 & 5.7 & 4.1 & 2.9 & 1.7 & -69.5 & 0.33 \\
\hline New Zealand & 4.9 & 5.2 & 4.1 & 3.0 & 2.0 & 2.1 & -57.4 & 0.34 \\
\hline Norway & 5.5 & 5.5 & 4.6 & 3.6 & 3.2 & 2.5 & -54.9 & 0.24 \\
\hline Portugal & 5.9 & 5.9 & 5.4 & 5.1 & 4.4 & 2.9 & -51.7 & 0.19 \\
\hline Spain & 5.0 & 5.0 & 4.9 & 4.5 & 3.5 & 2.2 & -57.0 & 0.21 \\
\hline Sweden & 4.5 & 4.5 & 4.4 & 3.3 & 2.4 & 2.0 & -56.5 & 0.28 \\
\hline Switzerland & 4.1 & 4.2 & 4.2 & 4.2 & 3.7 & 2.9 & -30.3 & 0.11 \\
\hline United Kingdom & 4.8 & 4.5 & 3.8 & 2.1 & 1.4 & 1.1 & -76.7 & 0.47 \\
\hline United States & 3.7 & 2.8 & 2.4 & 2.2 & 1.6 & 1.4 & -61.6 & 0.27 \\
\hline
\end{tabular}

1. Simple averages of indicators for 7 industries : gas, electricity, post, telecoms, air transport, railways, road freight. Depending on the industry the following dimensions have been included : barriers to entry, public ownership, market structure, vertical integration, price controls.

\title{
The relationship between labour and product market policies
}

35. The analysis of policies and regulations in the product and labour markets can be combined to investigate the features of the overall policy environment across OECD countries. Interestingly, the indicators of product and labour markets suggest that, in general, restrictive product market regulations were matched by analogous EPL restrictions over the sample period. The cross-country correlation between the summary indicators of product market regulation and EPL is 0.72 (significant at the $1 \%$ level) (Figure 3). The correlation remains high and significant if we summarise all labour market policies - i.e., tax wedges, gross replacement rates and EPL - in a single score that is increasing in the three indicators, even though the dispersion across countries increases. ${ }^{26}$ This score can be thought of as a summary indicator of labour market policies and will be used in later empirical analysis to address potential multicollinearity problems related to the complementarity between policies (see below for more details). It should be noticed that these correlations are robust to changes in both the period and the definition of product market regulation (non-manufacturing or economy-wide).

26. Country scores were derived by weighting the three policies with the scoring coefficient attached to the first principal component (extracted by means of standard principal components analysis). 
36. To clarify further the relationship between product and labour market policies, we used cluster analysis to identify groups of countries that share common patterns across the two sets of policies. The analysis was performed using as basic data the period averages of the summary indicator of product market regulation together with either the indicator of EPL or the summary indicator of labour market policies. In both cases, four main clusters emerged:

- The first cluster includes most of the common-law countries (the United States, the United Kingdom, Canada, Australia and New Zealand). They were characterised over the sample period by a relatively liberal approach in both the labour and product markets.

- The second cluster includes most continental European countries and Japan. They shared relatively restrictive product market policies and EPL. However, when account is made of a wider set of labour market policies, Japan is isolated from this group, due to relatively low tax wedges and replacement rates.

- The third cluster includes Ireland and Switzerland (joined by Japan when all labour market policies are accounted for), which had relatively restrictive product market regulations but a more lenient labour market approach.

- Finally, the fourth cluster includes some southern European countries (Greece, Italy and Portugal), joined by France when all labour market policies are covered. They combined very restrictive approaches in both the labour and product markets.

37. Thus, restrictive regulations in the product market tend to be associated with restrictive labour market policies, resulting in both weak product market competition and stickiness in labour reallocation. As already mentioned, this correlation tends to support the idea that policies in the two areas are political complements. For example, by increasing the speed of labour market adjustment, less restrictive EPL may make regulatory reform in the product market easier to implement. ${ }^{27}$ Conversely, restrictive product market regulations may make it less urgent for entrepreneurs to lobby for and for workers to accept an easing of EPL. At the same time, in firms sheltered from competitive pressures (either by legal, administrative and trade restrictions or public ownership) the insider power of workers may be higher, leading to greater protection from dismissals. This would suggest that, by lowering insider power, deregulation could facilitate labour market reform. Experience with reform in OECD countries tends to support this political economy link: there is a positive cross-country correlation between a summary index of labour market reform and the lagged indicator of product market reform in the non-manufacturing industries (Brandt $e t$ al., 2005).

38. Explaining the way in which interactions between agents' incentives and government policies may jointly shape regulatory environments in the labour and product markets is beyond the scope of this paper. ${ }^{28}$ Notably, this would require investigating whether reforms in one set of policies would induce changes in the other, as well as whether complementarity is not generated by a third set of factors that influences policy choices in both product and labour markets. Nonetheless, the existence of the political economy link just discussed could have implications for the way product and labour market policies interact to determine long-run employment outcomes. On the one hand, we might expect rent-generating regulations to have more detrimental effects on employment in the presence of labour market policies that favour insider power. On the other hand, we might expect deregulation to have stronger effects on

27. A lax EPL regulation may, however, make workers' resistance to regulatory reform fiercer insofar as insiders would be less protected in the event of redundancies.

28. An analysis of the political economy of structural reform can be found in Galasso et al., (2005). 
aggregate employment in the long run if it was implemented in a restrictive labour market environment. This is for two related reasons. First, employment rates will tend to be lower in restrictive labour markets, potentially increasing the scope for employment gains from product market deregulation. Second, the reduction in product market rents induced by stronger competitive pressures may translate over time into weaker insider power and a more flexible labour market, leading to employment gains over and above those that are directly due to deregulation. The possible political complementarity between product and labour market policies also raises a model specification issue. While omission of product market policies from the analysis of the determinants of employment can lead to serious bias, strong complementarity between these policies and certain labour market provisions (e.g., EPL) creates potential identification problems when both sets of policies are accounted for in empirical analysis. We will try to address some of these issues in the next section.

\section{Regulations and labour market performance}

39. Can differences in the employment rates (the share of the employed relative to the working age population) of OECD countries be explained by diverging policies and institutions in labour and product markets? Using the policy indicators described above, we first examine prima facie evidence that labour and product market regulations may be correlated with the employment rate. We then turn to a more in-depth analysis of their potential effects on employment in a multivariate estimation framework.

\section{Bivariate evidence}

40. Figure 4 plots the evolution of the employment rates (total and for the non-agricultural business sector) in the OECD countries over the entire sample period covered by our empirical analysis. ${ }^{29}$ There are clearly significant differences in the shares of working age population that are employed, especially in the non-agricultural business sector where employment rates range from $40 \%$ in Greece to almost $65 \%$ in Japan. There have also been different employment trends over time. Employment rates have increased over the past two decades in North American countries, Japan, the United Kingdom, Ireland and some other smaller European countries. In contrast, they have fallen significantly in some of the Nordic countries in the early 1990s (from very high levels). In most other European countries employment rates have been fairly stable or slightly declining. Differences in the levels and trends of employment rates are partly related to policies that affect the decision of certain groups (youths, women and elderly in particular) to enter or remain in the labour market, as well as to the role of the state as an employer in the economy. ${ }^{30}$ Do these patterns of employment also relate to regulations in the product and labour markets?

29. Switzerland must be dropped due to lack of complete employment data for the non-agricultural business sector.

30. For instance, a strong empirical relationship has been found between the large differences in old-age employment rates and early retirement incentives provided by pension and income support systems (Duval, 2003). 
Figure 3. Labour and product market policies in OECD countries ${ }^{1}$ (average 1981-2002)

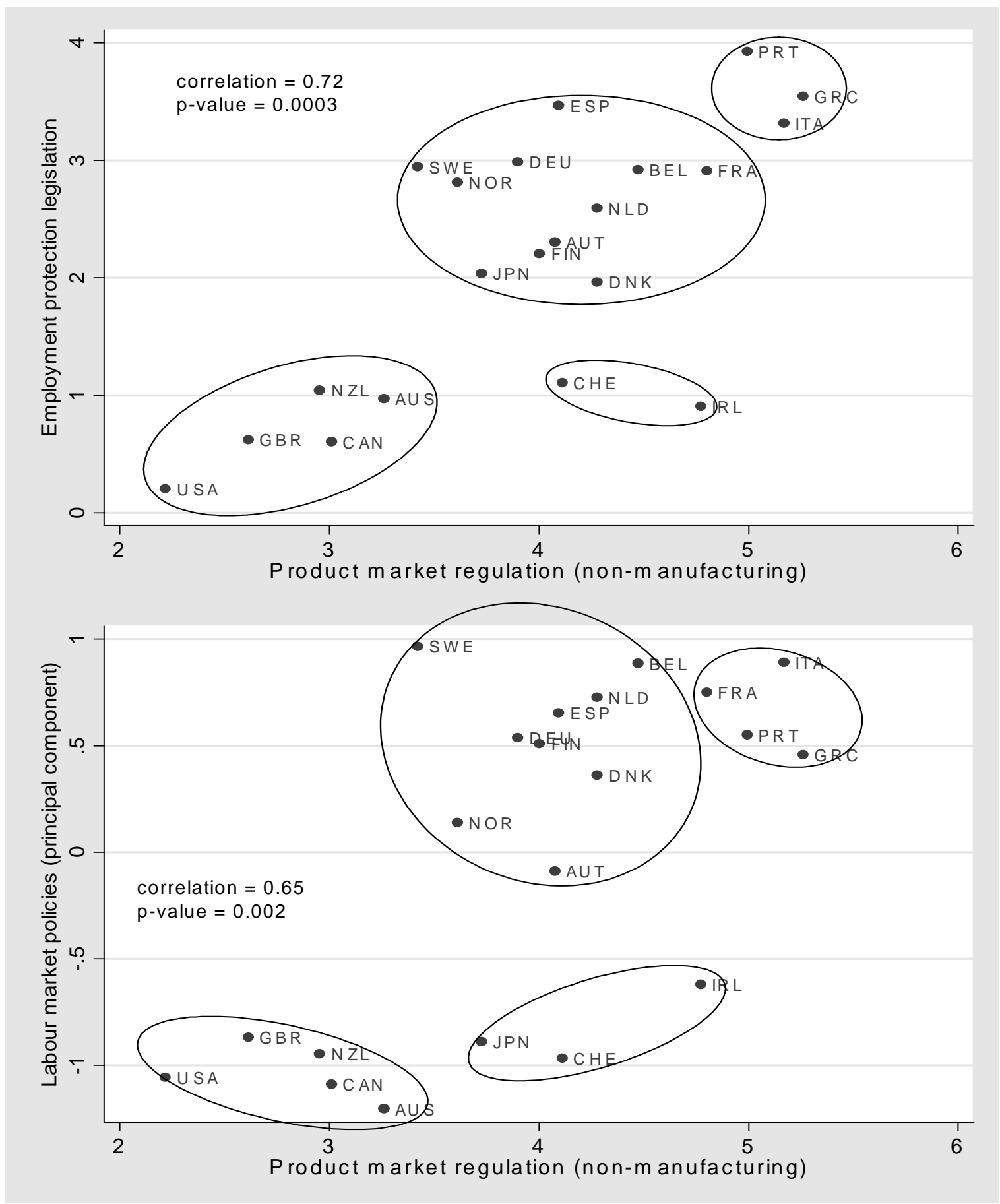

1. The principal component of labour market policies scores countries (from least to most restrictive) according to tax wedges, gross replacement rates and employment protection legislation.

2. Circles indicate country groupings identified by performing cluster analysys (Ward's method) on pairs of indicators 
Figure 4. Employment rates

(per cent of working age population)

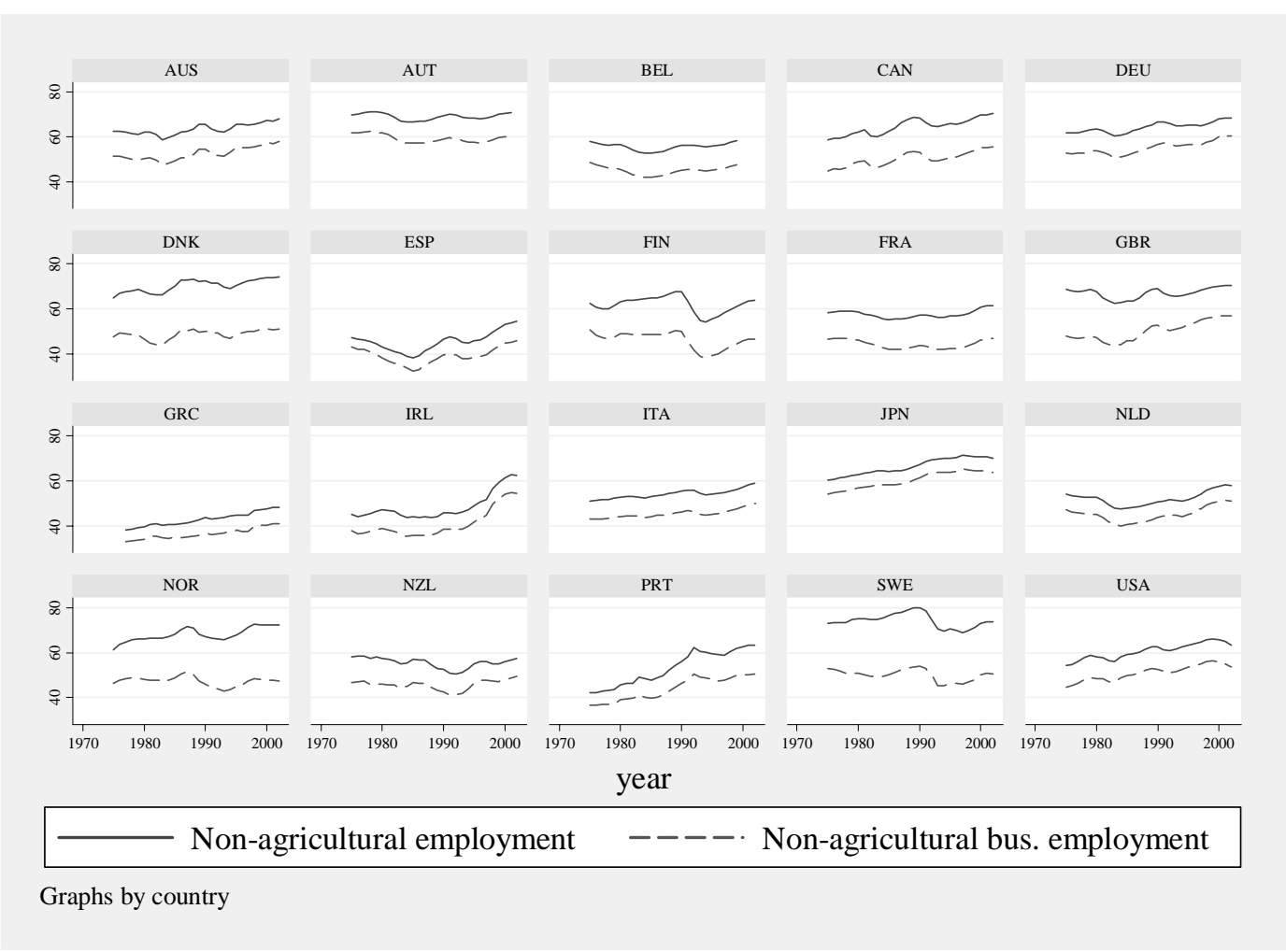

41. Figure 5 sheds prima facie evidence to this question by plotting non-agricultural employment rates across countries and time against either the product market or the labour market synthetic indicators. ${ }^{31}$ In both cases there is a significant correlation between the employment rate and regulations in the two markets: tight EPL regimes tend to be associated with a lower proportion of employment in the non-agricultural business sector (correlation $=-0.35$ ); the relationship between product market regulation and business sector employment is even stronger (correlation $=-0.5$ ). To understand whether these bivariate correlations reflect an effect of policies on equilibrium employment rates, we now turn to a more thorough empirical analysis, accounting for the simultaneous effect of both product and labour market policies and controlling for other factors that could affect employment rates.

31. Agricultural employment is not considered in the figure given the large proportion of self-employed workers in that sector, who are only marginally affected by the product and labour market regulations examined in this paper. 
Figure 5. Employment and regulations, 1981-2002
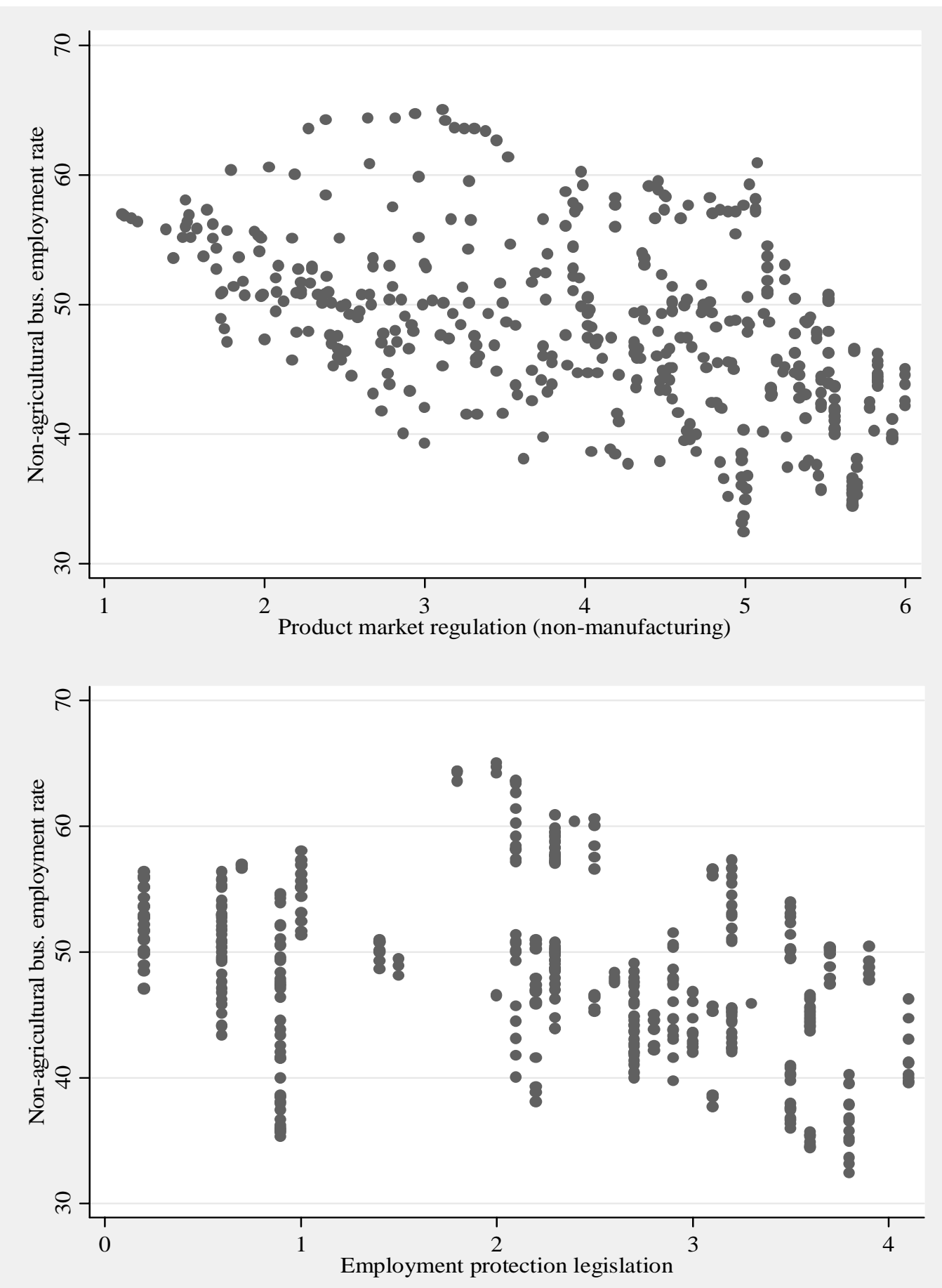

\section{A multivariate analysis}

42. Our multivariate analysis assumes that the employment rate depends on a number of factors shaping the demand and supply of labour in addition to our indicators of labour and product market policies. In particular, we control for bargaining institutions, interactions among policies and with 
institutions, the cycle and other unexplained country and time-specific effects. The empirical specification stems from the familiar Jackman et al., (1991) bargaining model, but it is also consistent with the channels of product-labour market interactions identified by the more recent research discussed above. The essential features of this model are an upward sloping wage-setting schedule, based on the assumption that real wages are the result of a bargaining process between employers and employees, who are able to exert some market power, combined with a downward sloping labour demand schedule. The labour demand schedule is influenced by product market conditions, while the wage-setting schedule is influenced by wage push factors, including labour market policies, the strength of workers in the wage bargaining process and bargaining arrangements. Product market policies enter the picture because they affect the market power of firms and the associated rents, which are important determinants of wages and equilibrium employment.

43. The dependent variable in our equations is the non-agricultural employment rate, the component of employment most directly influenced by labour and product market policies and institutions. ${ }^{32} \mathrm{We}$ experiment with both total non-agricultural and business non-agricultural employment rates. In the latter case, we separately control for the share of public employees in the working-age population (the public employment rate) to test for the hypothesis that the latter may crowd out employment opportunities in the business sector. A significantly negative coefficient would support this hypothesis. However, since public and private employment rates are likely to be co-determined, we instrument the current public employment rate with the average of the previous two years $\left(t_{-2}\right.$ and $\left.t_{-1}\right)$.

44. Denoting the public employment rate by egr, the indicators of labour market policies and institutions by $\operatorname{lm} r$ and inst (two vectors of variables or a summary indicator of them, depending on the specification), respectively, and our indicator of product market regulation by $p m r$, the reduced-form equation for the equilibrium non-agricultural business employment rate $(e b r)$ is:

$$
\begin{aligned}
e b r_{i t} & =\mu_{0}+\mu_{i}+\tau_{i}+\alpha \cdot e g r_{i t}+\sum_{k} \beta_{k} \cdot \operatorname{lm} r_{k i t}+\sum_{k} \phi_{k} \cdot \text { inst }{ }_{k i t}+\sum_{k} \gamma_{k} \cdot(\text { inst } \cdot \operatorname{lm} r)_{k i t} \\
& +\delta p m r_{i t}+\sum_{k} \theta_{k}(p m r \cdot \operatorname{lm} r)_{k i t}+\sum_{k} \sigma_{k} \cdot(\text { inst } \cdot p m r)_{k i t}+\lambda \cdot g a p{ }_{i t}+v_{i t}
\end{aligned}
$$

where $i$ indexes countries; $t$ indexes years; $k$ indexes different policy or institutional variables; $g a p_{i t}$ is the output gap, included to account for changes in the business cycle, ${ }^{33} \mu_{0}$ is a constant term; $\mu_{i}$ is the countryspecific effect not accounted for by the available explanatory variables; $\boldsymbol{T}_{i}$ is the country-specific time trend; and $v_{i t}$ is the usual error term.

45. Policy and institutional variables cover the product and labour market areas already discussed as well as the system of wage bargaining. The latter includes union density (the proportion of workers who are members of trade unions) and the form of bargaining. We use union density as a proxy for the bargaining power of workers, though it should be noticed that this variable does not necessarily reflect such power in countries where administrative extension of collective agreements is in place. A better proxy would be the share of workers covered by these agreements, but available data on coverage are too patchy

32. Estimates using the total and business employment rate showed that agricultural employment can safely be ignored in these regressions. The results of these preliminary estimates are available upon request.

33. The gap variable is defined as the proportional difference between actual and potential output, where the latter is from the OECD Economic Outlook. The assumption of an identical parameter for the gap variable across all cross-sectional units does not affect significantly the estimated coefficients for the other explanatory variables. An alternative equation with country-specific coefficients for this variable produced similar results. Results remained unchanged also in another specification where the gap variable was instrumented with its lagged value to account for potential endogeneity of employment and output along the business cycle. 
to be used in empirical analysis (OECD, 2004). The form of bargaining has been shown to be an important determinant of equilibrium employment (unemployment) (Bruno and Sachs, 1985; Elmeskov et al., 1998; Nickell and Layard, 1998), with some evidence that both decentralised and centralised systems are preferable to intermediate ones based on bargaining at the industry level (Flanagan, 1998; OECD, 1997). The bargaining indicator we use combines two features: the level of bargaining, which can be centralised, intermediate (at the industry or regional level), or decentralised (at the firm level); and the degree of co-ordination among, on the one hand, employers' associations and, on the other hand, trade unions. Combining these two features makes it possible to consider cases where co-operation between employers and unions in an industry-level bargaining system (e.g., Germany and Austria and, more recently, Italy, Ireland and the Netherlands) may be a functionally-equivalent alternative to centralised systems. This is because strong coordination allows industry unions to internalize the aggregate effects of their wage decisions into the negotiation process, de facto mimicking the outcomes of a highly centralized bargaining regime.

46. In keeping with our earlier discussion of policies and institutions, we include different types of possible interactions. In particular, we test the hypothesis that the effect of employment protection legislation on employment depends on the form of bargaining, reflecting different degrees of internalisation of the consequences of such legislation for aggregate employment (lmr.inst). We also test the possible complementarity of labour market policies and institutions with product market regulation by letting the effects of regulation on employment vary with the policy stance and bargaining settings in the labour market (pmr.lmr and pmr-inst). The precise way in which these interactions are defined is described below.

47. As noted by some authors, a pitfall of jointly estimating the effect of policies and institutions on employment is that these variables are often closely correlated, as illustrated in the previous section, with many of them also displaying pronounced time trends. ${ }^{34}$ This creates multicollinearity that makes precise estimates of the coefficients of interest elusive, especially when country-specific trends are accounted for. Following the same approach as in Figure 3 above, we address this problem in some of the regression estimates by constructing three synthetic indicators summarizing the characteristics of the labour market in each country. The first (lmr) focuses on labour market policies and covers unemployment benefits, employment protection and the tax wedge. The second (inst) focuses on institutional variables and includes unionisation as well as the centralization and coordination of wage bargaining. The third (lmrinst) combines policies and institutions in a single indicator of the "labour market setting". Each synthetic indicator is calculated as the first component of a standard principal components analysis performed on the two sets of variables. Countries are "scored" along these components using the estimated weights. ${ }^{35}$ Since these weights reflect the contribution of each indicator to the overall variance, the synthetic indicators have the desirable property of accounting for most of the variability contained in the original data. At the same time, their use in regressions reduces collinearity problems, allowing more precise estimates of the effects of product market regulation on employment.

34. The tables in the annex provide summary statistics and correlations among the variables used in regressions.

35. With the scoring coefficients based on the rotated factors, the resulting summary indicators were calculated as follows:

inst $=0.26 \cdot$ coordination $+0.54 \cdot$ centralisation $+0.18 \cdot$ unionisation

lmr $=0.48 \cdot$ tax wedge $+0.1 \cdot$ replacement rate $+0.38 \cdot$ epl

lmrinst $=0.13 \cdot$ coordination $+0.4 \cdot$ centralisation $+0.1 \cdot$ unionisation $+0.22 \cdot$ tax wedge $+0.09 \cdot$ replacement rate $+0.28 \cdot$ epl 
ECO/WKP(2005)59

\section{Empirical results}

48. Tables 2-4 present the regression results obtained in a panel of 20 OECD countries over the 1980-2002 period. ${ }^{36}$ Our estimation strategy is the following. We begin with "baseline" regressions that do note use principal components of labour market policies and institutions and do not include product-labour market policy interactions (Table 2). We use these regressions to select the appropriate dependent variable, test for heteroskedasticity and multicollinearity, identify influential observations and test for time trends. We then turn to regressions that correct for heteroskedasticity and include principal components and country-specific time trends (Table 3). Finally, we look at interactions between product market regulations and labour market policies and institutions (Table 4). Each equation was first estimated using OLS, and the presence of unobservable country-specific effects was verified by a conventional F-test. ${ }^{37}$ Since the null hypothesis of cross-country equality of the constant term was always rejected at conventional significance levels, we only show estimates of fixed-effects specifications.

\section{General characteristics of the estimated equations}

49. Before discussing in detail estimation results concerning the variables of interest, it is useful to look at the broad statistical properties of the various model specifications. The diagnostic tests in Table 2 have several implications. First, the Breusch-Pagan test detects heteroskedasticity in the data, suggesting the use of robust estimators in all regressions. Second, the data seems to reject total non-agricultural employment rate as a dependent variable, which implicitly imposes a one-to-one substitution effect between public and private employment. Both the regression $\mathrm{R}^{2}$ and the Ramsey test improve when a more flexible specification using the non-agricultural business employment rate as the left-hand side variable is chosen and the public sector employment rate appears on the right-hand-side, i.e., when the degree of substitution is left unrestricted. Third, and most important, the Ramsey test suggests that omission of the product market regulation variable would lead to mispecified employment rate equations. Finally, standard tests for influential observations revealed the presence of significant outliers in the data, which consistently affected the standard error of the regression and/or the estimated coefficients. Thus, as a sensitivity check, we show regression results both including and excluding (estimation-specific) outlier observations. ${ }^{38}$

50. Equations in Table 2 were also estimated with country-specific time trends, which turned out to be always jointly significant based on standard F-tests. The time trends control for any unobserved dynamics that may drive non-agricultural business sector employment rates, such as for instance the continuous increase in female labour supply and/or productivity gains that are only partly embodied in real wage claims. Failing to account for these trends may cause spurious correlations between the dependent and the explanatory variables, but this potentially important source of bias has been often ignored in previous empirical studies. It should be noticed at the outset that estimates of product market regulation effects are robust to this change in model specification. More generally, the results of regressions excluding and including such trends are qualitatively consistent, but accounting for them changes the size

36. In the tables, the two variables referring to the centralisation/co-ordination of the wage bargaining indicate the effects of intermediate or high centralisation/co-ordination relative to that of decentralised systems. Details on country classification in terms of the different aspects of collective bargaining and countryspecific changes in bargaining arrangements over time can be found in Elmeskov et al., (1998) and OECD (2004).

37. In the presence of country-specific effects, OLS estimates are biased and the direction of the bias cannot be identified a priori (Moulton, 1986).

38. The outliers have been identified using the DFITS and the COVRATIO statistics, which, in turn, are based on the studentized residuals and the leverage values. The outliers are those annual observations for a given country that significantly increase the standard error of the regression or affect the estimated coefficients. The results of the tests are available on request. 
(and sometimes even the significance) of some of the estimated coefficients of labour market policies and institutions.

51. There is, however, an important issue related to model specification: the instability of the coefficient (and sign) of the public employment variable. This instability of results suggests that the use of the lagged value of the variable (as in Algan et al., 2002) is not enough to solve the endogeneity problem of the public employment variable, perhaps due to the strong persistence of public employment over time. ${ }^{39}$ It could also point to aggregation bias, whereby subcomponents of public employment with different time-series properties and different degrees of substitution with business employment are expressed by a single variable. We leave this important but thorny analytical issue to further research. For our analysis of policy and institutions, however, we need to make sure that the problems related to the public employment variable do not affect the estimates of the coefficients of interest. For that purpose, we replicated the main results omitting public employment (see Annex). It is reassuring to note that the coefficients of all the other variables turned out to be robust to this omission.

52. We now turn to a detailed discussion of the results concerning the influence of policies and institutions. To make the link with employment rate models estimated in other studies, we deal first with the effects of labour market policies and bargaining systems and then turn to the effects of product market regulation. Anticipating our findings on the labour market side, the evidence suggests that generous benefit systems, high labour tax wedges and high union density tend to curb employment rates, while results are more ambiguous concerning the effects of bargaining systems and EPL. In general, all the coefficient estimates are in line with results found in other empirical studies but the inclusion of country-specific time trends often makes their magnitudes more plausible.

39. The instability of the coefficient estimates on the public employment variable when country-specific time trends are introduced was also noted by Pischke (2002) in a comment made to Algan et al., (2002). 


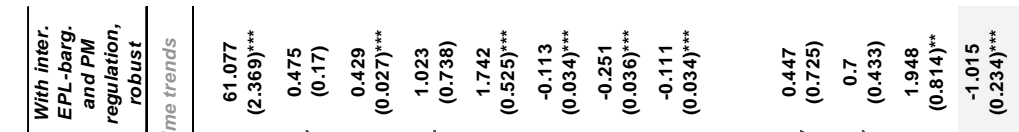

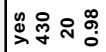

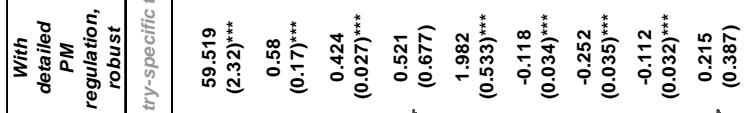

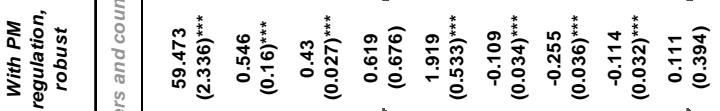

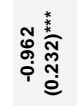

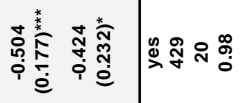

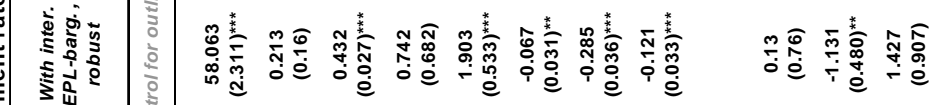

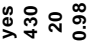

s.

我

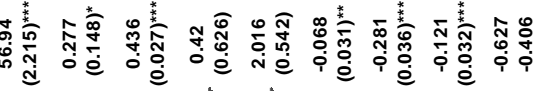

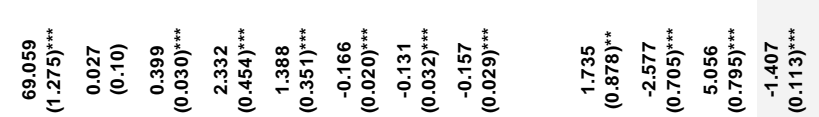

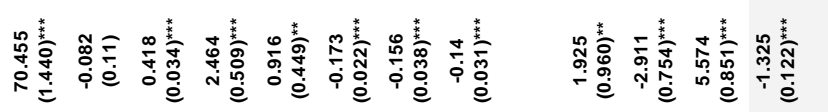

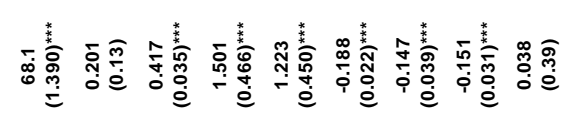

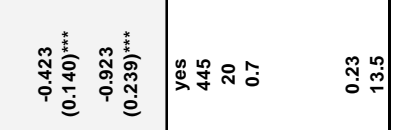

亦

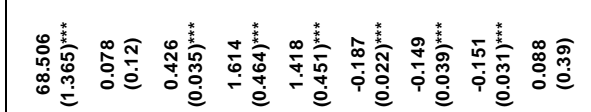

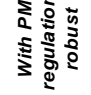

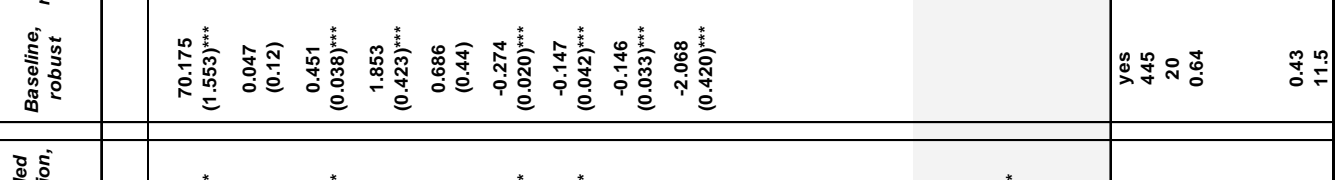

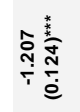

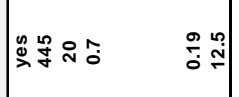

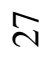

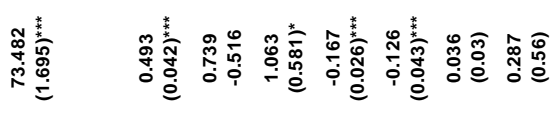

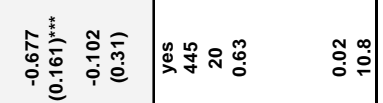

$\frac{7}{\frac{7}{4}}$

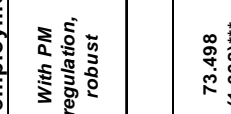

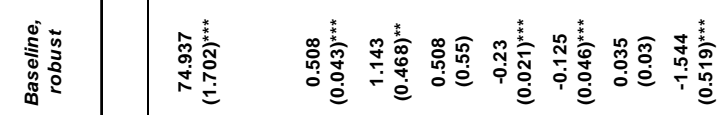

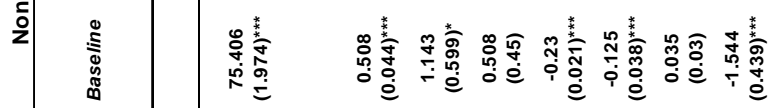

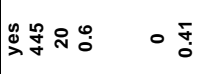

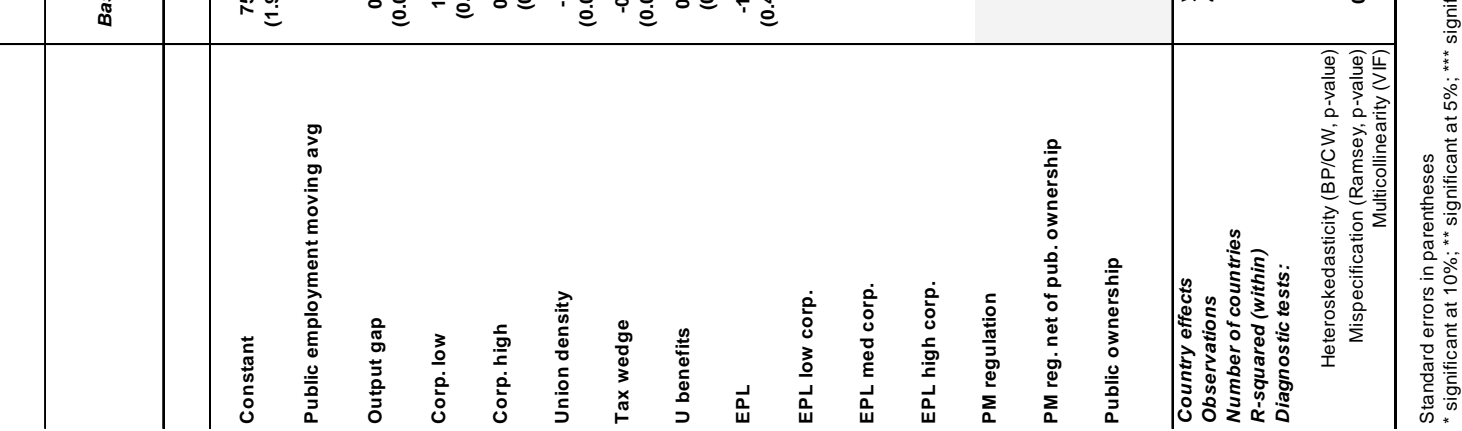


Table 3. Regressions with principal components of labour market policies and institutions

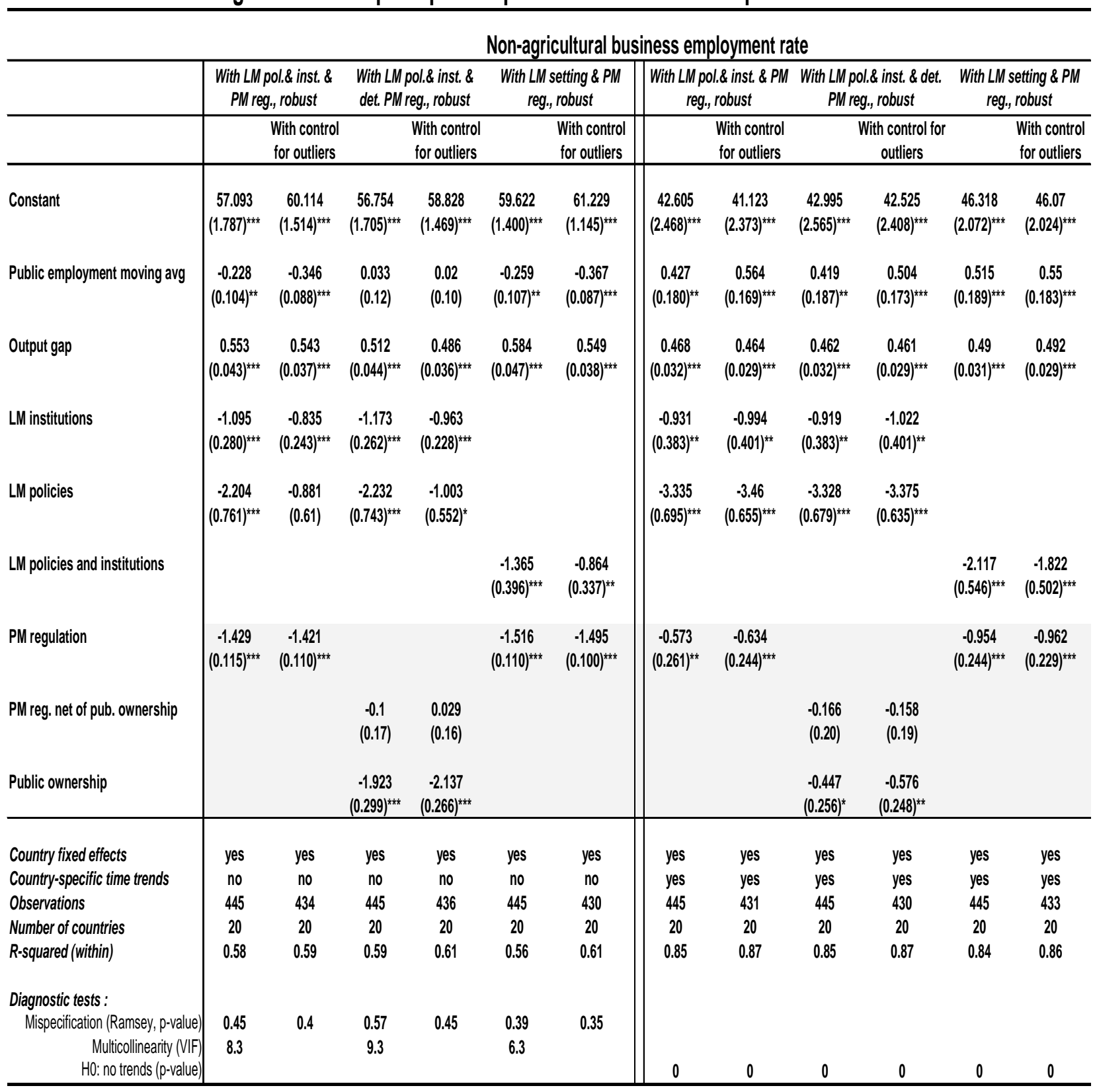

Standard errors in parentheses

${ }^{*}$ significant at 10\%; ${ }^{*}$ significant at $5 \%$; ${ }^{* * *}$ significant at $1 \%$ 
Table 4. Regressions with product market and labour market policy interactions

\begin{tabular}{|c|c|c|c|c|c|c|c|c|}
\hline & \multicolumn{8}{|c|}{ Non-agricultural business employment rate } \\
\hline & \multirow{2}{*}{\multicolumn{2}{|c|}{$\begin{array}{c}\text { With LM pol.\& inst. \& } \\
\text { PMR-LMR interactions, } \\
\text { robust } \\
\text { With control } \\
\text { for outliers }\end{array}$}} & \multirow{2}{*}{\multicolumn{2}{|c|}{$\begin{array}{c}\text { With LM pol.\& inst. \& } \\
\text { PMR-INST interactions, } \\
\text { robust } \\
\text { With control } \\
\text { for outliers }\end{array}$}} & \multicolumn{2}{|c|}{$\begin{array}{c}\text { With LM setting \& PMR } \\
\text { interactions, robust }\end{array}$} & \multicolumn{2}{|c|}{$\begin{array}{l}\text { With LM inst., PM reg. \& PMR- } \\
\text { LMR interactions, robust }\end{array}$} \\
\hline & & & & & & $\begin{array}{l}\text { With control } \\
\text { for outliers }\end{array}$ & & $\begin{array}{c}\text { With control for } \\
\text { outliers }\end{array}$ \\
\hline Constant & $\begin{array}{c}41.284 \\
(2.372)^{\star \star \star}\end{array}$ & $\begin{array}{c}40.102 \\
(2.305)^{\star \star \star}\end{array}$ & $\begin{array}{c}41.235 \\
(2.489)^{\star \star \star}\end{array}$ & $\begin{array}{c}38.908 \\
(2.330)^{\star \star \star}\end{array}$ & $\begin{array}{c}45.053 \\
(2.205)^{\star \star \star}\end{array}$ & $\begin{array}{c}43.334 \\
(2.585)^{\star \star \star}\end{array}$ & $\begin{array}{c}43.12 \\
(2.653)^{\star \star \star}\end{array}$ & $\begin{array}{c}42.038 \\
(2.602)^{\star \star \star}\end{array}$ \\
\hline Public employment moving avg & $\begin{array}{c}0.465 \\
(0.179)^{\star \star \star}\end{array}$ & $\begin{array}{c}0.566 \\
(0.170)^{\star \star \star}\end{array}$ & $\begin{array}{c}0.503 \\
(0.179)^{\star \star \star}\end{array}$ & $\begin{array}{c}0.647 \\
(0.166)^{\star \star \star}\end{array}$ & $\begin{array}{c}0.513 \\
(0.189)^{\star \star \star}\end{array}$ & $\begin{array}{c}0.557 \\
(0.191)^{\star \star \star *}\end{array}$ & $\begin{array}{c}0.382 \\
(0.198)^{\star}\end{array}$ & $\begin{array}{c}0.5 \\
(0.186)^{\star \star \star}\end{array}$ \\
\hline Output gap & $\begin{array}{c}0.452 \\
(0.030)^{\star \star \star}\end{array}$ & $\begin{array}{c}0.452 \\
(0.027)^{\star \star \star}\end{array}$ & $\begin{array}{c}0.458 \\
(0.030)^{\star \star \star}\end{array}$ & $\begin{array}{c}0.461 \\
(0.026)^{\star \star \star}\end{array}$ & $\begin{array}{c}0.49 \\
(0.031)^{\star \star \star}\end{array}$ & $\begin{array}{c}0.497 \\
(0.030)^{\star \star \star}\end{array}$ & $\begin{array}{c}0.46 \\
(0.033)^{\star \star \star}\end{array}$ & $\begin{array}{c}0.459 \\
(0.030)^{\star \star \star}\end{array}$ \\
\hline LM institutions & $\begin{array}{c}-0.879 \\
(0.384)^{\star \star}\end{array}$ & $\begin{array}{l}-1.086 \\
(0.412)^{\star \star \star}\end{array}$ & $\begin{array}{r}0.695 \\
-0.955\end{array}$ & $\begin{array}{r}1.471 \\
-0.925\end{array}$ & & & $\begin{array}{c}-0.936 \\
(0.382)^{\star \star}\end{array}$ & $\begin{array}{c}-1.012 \\
(0.400)^{\star \star}\end{array}$ \\
\hline LM policies & $\begin{array}{c}-1.97 \\
(0.693)^{\star \star *}\end{array}$ & $\begin{array}{c}-2.091 \\
(0.649)^{\star \star \star}\end{array}$ & $\begin{array}{c}-2.908 \\
(0.668)^{\star \star \star}\end{array}$ & $\begin{array}{c}-2.922 \\
(0.598)^{\star \star \star}\end{array}$ & & & & \\
\hline LM policies and institutions & & & & & $\begin{array}{c}-2.032 \\
(0.545)^{\star \star \star}\end{array}$ & $\begin{array}{c}-2.06 \\
(0.564)^{\star \star \star}\end{array}$ & & \\
\hline PM regulation & & & & & & & $\begin{array}{l}-0.593 \\
(0.261)^{\star *}\end{array}$ & $\begin{array}{c}-0.644 \\
(0.245)^{\star \star \star}\end{array}$ \\
\hline PM reg. in high LMR & $\begin{array}{c}-0.847 \\
(0.250)^{\star \star \star}\end{array}$ & $\begin{array}{c}-0.842 \\
(0.236)^{\star \star \star}\end{array}$ & & & & & & \\
\hline PM reg. in med. LMR & $\begin{array}{c}-0.59 \\
(0.263)^{\star \star}\end{array}$ & $\begin{array}{c}-0.604 \\
(0.248)^{\star \star}\end{array}$ & & & & & & \\
\hline PM reg. in low LMR & $\begin{array}{c}-0.043 \\
-0.27\end{array}$ & $\begin{array}{l}-0.06 \\
-0.257\end{array}$ & & & & & & \\
\hline PM reg. in high INST & & & $\begin{array}{c}-0.907 \\
(0.292)^{\star \star \star}\end{array}$ & $\begin{array}{c}-0.943 \\
(0.266)^{\star \star \star}\end{array}$ & & & & \\
\hline PM reg. in med. INST & & & $\begin{array}{c}-0.52 \\
(0.275)^{\star}\end{array}$ & $\begin{array}{c}-0.476 \\
(0.254)^{*}\end{array}$ & & & & \\
\hline PM reg. in low INST & & & $\begin{array}{l}-0.319 \\
-0.346\end{array}$ & $\begin{array}{l}-0.117 \\
-0.336\end{array}$ & & & & \\
\hline PM reg. in high LMR\&INST & & & & & $\begin{array}{c}-0.956 \\
(0.271)^{\star \star \star}\end{array}$ & $\begin{array}{c}-0.926 \\
(0.297)^{\star \star \star}\end{array}$ & & \\
\hline PM reg. in med. LMR\&INST & & & & & $\begin{array}{c}-1.047 \\
(0.253)^{\star \star \star}\end{array}$ & $\begin{array}{c}-1.028 \\
(0.277)^{\star \star \star}\end{array}$ & & \\
\hline PM reg. in low LMR\&INST & & & & & $\begin{array}{c}-0.733 \\
(0.319)^{\star \star}\end{array}$ & $\begin{array}{l}-0.426 \\
-0.357\end{array}$ & & \\
\hline LM pol. in high PMR & & & & & & & $\begin{array}{c}-3.209 \\
(0.712)^{\star \star \star}\end{array}$ & $\begin{array}{c}-3.32 \\
(0.672)^{\star \star \star}\end{array}$ \\
\hline LM pol. in med. PMR & & & & & & & $\begin{array}{c}-3.474 \\
(0.742)^{\star \star \star}\end{array}$ & $\begin{array}{c}-3.48 \\
(0.720)^{\star \star \star}\end{array}$ \\
\hline LM pol. in low PMR & & & & & & & $\begin{array}{c}-3.623 \\
(0.724)^{\star \star \star}\end{array}$ & $\begin{array}{c}-3.798 \\
(0.659)^{\star \star \star}\end{array}$ \\
\hline Country fixed effects & yes & yes & yes & yes & yes & yes & yes & yes \\
\hline $\begin{array}{l}\text { Country-specific time trends } \\
\text { Observations }\end{array}$ & $\begin{array}{l}\text { yes } \\
445\end{array}$ & $\begin{array}{l}\text { yes } \\
431\end{array}$ & $\begin{array}{l}\text { yes } \\
445\end{array}$ & $\begin{array}{l}\text { yes } \\
432\end{array}$ & $\begin{array}{l}\text { yes } \\
445\end{array}$ & $\begin{array}{l}\text { yes } \\
433\end{array}$ & $\begin{array}{l}\text { yes } \\
445\end{array}$ & $\begin{array}{l}\text { yes } \\
431\end{array}$ \\
\hline $\begin{array}{l}\text { Number of countries } \\
\text { R-squared }\end{array}$ & $\begin{array}{c}20 \\
0.86\end{array}$ & $\begin{array}{c}20 \\
0.89\end{array}$ & $\begin{array}{c}20 \\
0.85\end{array}$ & $\begin{array}{c}20 \\
0.88\end{array}$ & $\begin{array}{c}20 \\
0.84\end{array}$ & $\begin{array}{c}20 \\
0.86\end{array}$ & $\begin{array}{c}20 \\
0.85\end{array}$ & $\begin{array}{c}20 \\
0.87\end{array}$ \\
\hline
\end{tabular}

\section{Effects of labour market policies and institutions}

Taxes, benefits and EPL

53. Estimates including country-specific trends imply that a 10 percentage point increase in tax wedges would lower the long-run employment rate by around 2.5 percentage points, while raising 
replacement rates by the same amount would have less than half this effect (Table 2, last four columns). Thus, in the average OECD country, market imperfections appear to be strong enough to prevent full tax shifting onto wages, confirming previous findings by Nickell et al., (2002), Elmeskov et al., (1998) and Nicoletti et al., (2001). Moreover, on average, the effects of overly generous benefits (in levels and/or duration) on the reservation wage of unemployed job-seekers would seem to dominate the positive impact on search effectiveness through income support, thereby leading to lower equilibrium employment rates.

54. Identifying the influence of EPL on employment has often been difficult both because it has $a$ priori conflicting effects on hiring and firing and because there was relatively little variation in this policy over time, especially for permanent contracts. Interestingly, in our estimates the negative effects of stringent EPL on employment rates tend to disappear when account is made of both product market regulation and country-specific time trends. While (consistent with previous literature) a negative effect persists in intermediate bargaining systems even after controlling for regulation, this effect vanishes when time trends are introduced as well. This suggests that previous (significantly negative) estimates obtained omitting such variables were partly spurious, possibly capturing contemporaneous movements in these variables and employment rates. Moreover, to the extent that deregulation spurs changes in EPL for the political economy reasons highlighted above, the indicator of regulation may capture some of the information relevant for explaining the influence of EPL on employment rates. This issue is not pursued here, but clearly deserves further research.

\section{The role of bargaining institutions}

55. While unionisation has a uniform negative effect on employment rates across specifications, the estimated coefficients for the measures of centralisation/co-ordination (intermediate bargaining systems are the reference group) give very limited support to the hump-shaped hypothesis (Calmfors and Driffill, 1988). According to this view, both highly centralised/co-ordinated systems and fully decentralised systems should help restrain the wage claims of insiders and raise employment, while intermediate systems would not. In regressions with country-specific trends, decentralised systems do not induce significant employment gains relative to intermediate systems, while centralised/coordinated systems do so. The same is found when interacting EPL with bargaining regimes. This is surprising at first glance. In practice, however, to assess the combined effect of the institutional setting in each country, the effect of unionisation and corporatism should be jointly taken into account, because highly centralised and/or coordinated countries are generally characterized by a relatively high union density, whose negative effect on employment would tend to offset the other factors.

\section{Overall labour market conditions}

56. When we account for the complementarity among policies (lmr) and among institutions (inst) in the labour market (Table 3), both our synthetic indicators have a negative and significant impact on employment rates. Thus, the combination of, on the one hand, strict EPL, a generous benefit system and a high tax wedge and, on the other hand, of a high union density and a corporatist bargaining system are both detrimental for employment according to our estimates. Since the range of the $\operatorname{lm} r$ indicator is [-1.5, 1.4], estimates including country-specific time trends suggest that the effect of moving from relatively restrictive to relatively lax labour market policies would be to increase the employment rate by between 6 and 9 percentage points in the long-run, depending on whether the model includes product-labour market interactions or not. This is well within the range of employment rate movements observed over the past two decades in OECD countries. Interestingly, given the estimated weights for the three elements of the synthetic labour market policy indicator, only slightly lower employment gains would be obtained by easing tax wedges and EPL, while leaving benefit generosity unchanged (the Danish "flexicurity" model). This illustrates the importance of accounting for the possible relationships between policies in different labour market areas. Given that the inst indicator varies in the same range, the estimated employment gains 
associated with a move from a corporatist and highly unionised to a decentralised and low unionised bargaining setting would be much lower (around 3 percentage points). Consistent with these results, pooling policies and institutions into a single indicator (lmrinst) also suggests that moving towards a more restrictive labour market environment tends to curb employment rates.

\section{Product market regulation and its interaction with labour market policies}

57. We now turn to the effects of product market regulation on employment rates. Our synthetic indicator, which is increasing in state control and barriers to entry in competitive non-manufacturing markets, is estimated to significantly curb the employment rate in all regression specifications. In particular, the negative effect of regulation is robust to accounting for complementarities between policies and institutions that are controlled for by means of our synthetic indicators of labour market policies and institutions. However, as for other variables, the magnitude of this effect decreases when we account for country-specific time trends. Even so, reforms that would curb the highest state control and barriers to entry observed in the sample down to the best OECD practice (a 5 points decrease in the indicator) would increase long-run employment rates by between 2.5 and 5 percentage points, depending on the precise model specification. For instance, historically, product market reforms are estimated to have contributed to increase employment rates in the United Kingdom by between 2 and 4 percentage points and, extrapolating our estimates, further product market reforms aligning French regulations with current international "best practice" could increase long-run employment rates in France by up to 2 percentage points. ${ }^{40}$ Given that these are cross-market effects of policies, the estimates seem reasonable. However, to fully appreciate these results, it should be noticed that these are likely to be lower bound estimates of the potential effects of product market reforms on employment, because our indicator only covers reforms in a subset of nonmanufacturing industries. It should be added as well that regressions that distinguish between different kinds of product market interventions (state controls and barriers to entry) suggest that the contribution of privatisation and market liberalisation to increasing employment rates would be roughly equal in reforming countries, with the effect of liberalisation being more robust across model specifications.

58. Given the observed correlation between product and labour market policies, the average effects of deregulation discussed above may not be completely accurate. If policies in the two markets were to compound each other, the effects of regulation may depend on the labour market regime. For our purposes, two related empirical questions arise here. First, is the equilibrium employment rate lower in situations where both product and labour market policies are restrictive than in situations in which only one set of policies is restrictive? Second, does the impact of product market reform on employment depend on the degree of restrictiveness of labour market policies? For instance, one may expect employment losses to be higher in an economic environment characterised by both strict product market regulation and strong insider power in the labour market since, for the reasons already discussed, product market rents are likely to generate incentives for workers to use (and, possibly, strengthen) bargaining power to appropriate part of these rents. In certain bargaining settings (such as "right to manage"), this would tend to increase the wedge between wages and productivity relative to a more competitive situation in which product market rents would be lower. Conversely, in more flexible labour markets such sharing of rents would be minor, with lesser effects on the wage-productivity wedge and employment. In this scenario, reforms that reduce product market rents (such as privatisation and deregulation of state monopolies) would provide a double bonus to employment in restrictive labour markets: they would induce higher activity levels and new firm entry, while at the same time reducing rent-sharing and the wage-productivity wedge. This double bonus

40. Regulation is estimated to have a larger impact on employment rates than labour market institutions (our indicator summarising the degree of bargaining corporatism and union density). This could be due to the fact that product market reforms may drive changes in institutions, a link that is not explicitly accounted for in our framework. For instance, the generalised decline in union density in OECD countries could be partly due to the fall in rents implied by liberalisation (see Blanchard and Giavazzi, 2003). 
would be lacking in labour markets with less insider power, where employment would be boosted only by the reduction in product market rents.

59. To address this issue, we split our $\operatorname{lm} r$ and inst indicators in three groups defining different labour market regimes: highly restrictive (or highly corporatist), moderately restrictive (or moderately corporatist) and liberal (or decentralised). To account for interactions and complementarities across policies and institutions we also do the same with a principal component indicator pooling all characteristics of labour markets for which we have data (lmrinst) ${ }^{41}$ We then ran regressions interacting each of these regimes with our product market regulation variable (Table 4, first four columns). The results confirm our intuition: the estimated negative effects of product market regulation are stronger and more significant when labour market policies and institutions are more protective and costly. The reverse side of this is that, ceteris paribus, product market reforms have a larger impact on employment when labour market policies or institutions are restrictive. Thus, the bang-for-the-buck of deregulation, in terms of employment gains, is larger in restrictive and corporatist countries than in countries where labour market settings generate a weaker insider power of workers. This result is consistent with recent simulations of a model in which the effects of product market reforms on unemployment are much larger in countries with more powerful collective bargaining regimes than in those with decentralized bargaining regimes (Ebell and Haefke, 2003 and 2005). ${ }^{42}$

60. Our estimates suggest that the effects of product market deregulation on employment crucially depend on the ability of workers to appropriate rents by using the bargaining power that is ensured by labour market policies and institutions. However, is the reverse also true? Do the effects of labour market deregulation depend on the extent of product market rents ensured by regulation? The answer is not straightforward. On the one hand, labour market reforms that reduce insiders' bargaining power would tend to realign wages on productivity levels independent of the degree of product market competition. On the other hand, to the extent that more competitive pressures translate into a higher elasticity of labour demand to wages, one might expect a stronger effect of labour market reforms in countries with more liberal product markets. In the last two columns of Table 4 we test these conjectures by interacting our $\operatorname{lm} r$ indicator with different levels of product market regulation. To this end, we split the pmr indicator in three groups reflecting low, medium and high regulation (corresponding to the first quartile, the second quartile and the last two quartiles of the sample distribution, respectively). The estimated coefficients of labour market regulations in the different product market regimes are not statistically different. In other words, our results suggests that labour market reforms are likely to be equally beneficial for employment rates regardless of the degree of competitive pressures in product markets.

\section{Further sensitivity analysis}

61. The empirical analysis presented in this paper controls for the presence of outliers in the data set and for the possibility that omitted variables might result in country-specific trends in the employment

41. The groups correspond to situations in which the $1 \mathrm{mr}$ indicator is greater than 0.5 , in the range $[-0.5,0.5]$ or smaller than -0.5 . The results do not change if we take a dichotomic approach in which we subdivide countries into only two groups having either rigid or flexible labour markets.

42. Ebell and Haefke do not deal explicitly with labour market policies. Moreover, in their 2005 paper, they endogenise the bargaining system to the degree of product market regulation, with the model resulting in two alternative equilibria characterised by either low regulation and decentralised bargaining or high regulation and centralised bargaining. In reality, a continuum of situations exists in our data. Countries/periods that are classified as having low insider power constitute around one third of our observations, notably covering Australia, Canada, the United Kingdom, Ireland, Japan, New Zealand and the United States. All these countries have undergone significant product market deregulation over the sample period. 
series. To further assess the robustness of our results, we also perform two additional sensitivity tests. First we remove the public employment rate from the list of explanatory variables (see annex Table 1). As discussed above, the estimated coefficient for public employment is fairly unstable and sensitive to the inclusion of country-specific time trends. Hence we want to assess the robustness of results to the exclusion of this variable. Public employment trends may also reflect changes in public policies that are related to regulatory reforms in labour or product markets. Overall, the results suggest that the estimated coefficients for the variables of interest are robust to the exclusion of public employment from the equation.

62. Second, we perform the usual test of removing one country at the time from the sample. Here we are interested in the possible impact that one country might exert on the empirical results, over and above that of the country/year individual outliers. Such sensitivity tests are performed on the specification with synthetic indicators of labour market policies and institutions and product market regulations interacted with labour market policy (see column 2 in Table 4). In annex Figure 1, we present the estimated coefficients for product market regulation in countries with stricter labour market policy and institutions, where the effect is the strongest, as well as the coefficients for both the synthetic indicator of labour market policy and labour market institutions. ${ }^{43}$ The results suggests that the size of the estimated coefficients is somewhat sensitive to the exclusion of individual countries: the point estimate for product market regulation in countries with stringent policies is almost halved upon elimination of the Netherlands; and the coefficient for labour market institutions would suggest a much stronger negative effect on the employment rate when Italy is excluded from the sample. However, the point coefficient estimates for product market regulation, labour market policies and labour market institutions retain a negative sign and statistical significance at conventional levels in all the truncated samples.

\section{Concluding remarks}

63. Observed cross-country differences in employment rates can be partly explained by differences in both labour and product market policies. Our estimates suggest that regulations that curb competition and entry have had a negative impact that reduced significantly employment rates in OECD countries over the past three decades. By stimulating labour demand, product market deregulation can, therefore, be a useful complement to labour market reforms aimed at increasing labour utilisation. This supports theoretical research claiming that, at least in the long-run, increasing competitive pressures should be a priori good for employment. We also find that anti-competitive regulations tend to be costlier for employment when labour market policies and institutions protect insiders and enhance their bargaining power. Thus, the long-run employment gains from deregulation are larger in situations where workers' insider power is strong. A possible explanation is that, in the wake of liberalisation, employment is boosted both by the expansion of activity and entry and by a shrinking wage-productivity gap, as insiders lose their leverage on rents. When labour markets are more flexible, employment gains are smaller because they are obtained only through the first channel. This evidence is consistent with recent computable general equilibrium studies showing that the employment effects of deregulation are stronger in centralised bargaining settings than in decentralised ones.

64. Our results concerning the effect of regulation on employment are robust to changes in the definition of variables and the specification of models as well as to extensive sensitivity analysis. However, a number of extensions can be envisaged. First, further robustness checks could involve instrumenting or breaking down the public employment variable, for which puzzling results were found. Second, the analysis could be performed also on narrower definitions of employment, for instance excluding old-age workers whose employment rate is strongly affected by factors such as early retirement

43. The sensitivity analysis for the other coefficients and other model specifications is available from the authors on request. 
incentives that are not easy to account for in our sample due to limitations in the data. Third, to the extent that a political economy link between product market regulation and labour market policies and institutions partly works its way through employment outcomes, labour market policies may need to be instrumented to eliminate any potential endogeneity problem. The issue of policy complementarity, whose surface has just been scraped here, would certainly deserve additional research. This would involve explicitly testing the hypothesis that deregulation facilitates labour market reform. In this context, one would have to account for the possibility that the observed correlation between policy approaches in labour and product markets may reflect the influence of other factors that are jointly driving policy choices in the two areas, rather than the mere interplay between policy outcomes and incentives. For instance, candidates could be cross-country differences in cultural values and legal tradition or changes in political majorities that have parallel implications for policies in labour and product markets. Addressing some of these issues would require the estimation of a separate political economy model of how labour market policies are determined. 


\section{BIBLIOGRAPHY}

Akerlof, G. (1984), An Economist's Book of Tales, Cambridge University Press, Cambridge.

Alesina, A., S. Ardagna, F. Schiantarelli and G. Nicoletti (2003), "Regulation and investment", Journal of the European Economic Association, Vol.3, n.4, June 2005, pp.791-825.

Algan, Y., P. Cahuc and A. Zylberberg (2002), “Public Employment: Does it Increase Unemployment?", Economic Policy, No.34, April.

Amable, B. and D. Gatti (2001), "The Impact of Product Market Competition on Employment and Wages”, IZA Discussion Paper Series, 276.

Bentolila, S. and G. Bertola,. (1990), "Firing Costs and Labour Demand: How Bad is Eurosclerosis?", Review of Economic Studies, No.57, pp.381-402.

Bentolila, S. and J.J. Dolado (1994), “Labour Flexibility and Wages: Lessons from Spain”, Economic Policy, No.18, April.

Bertola, G. (1990), “Job Security, Employment and Wages", European Economic Review, Vol.34, North Holland, pp.851-886.

Bertola, G. and R. Rogerson (1997), “Institutions and Labor Reallocation”, European Economic Review Vol.41, pp.1147-1171.

Bertola, G. (1992), "Labour Turnover Costs and Average Labour Demand", Journal of Labour Economics, No.4.

Bertola, G., T. Boeri and S. Cazes (2000), "Employment Protection in Industrialized Countries: the case for New Indicators", International Labour Review, Vol.39, n.1.

Bertrand, M., and F. Kramarz, (2002), "Does Entry Regulation Hinder Job Creation? Evidence From The French Retail Industry”, Quarterly Journal of Economics, November, pp.1369-1413.

Blanchard, O. (2000), "The Economics of Unemployment. Shocks, Institutions, and Interactions", Lionel Robbins lectures.

Blanchard, O. and F. Giavazzi (2003), "Macroeconomic Effects of Regulations and Deregulation in Goods and Labor Markets", Quarterly Journal of Economics, 118, No.3:879-907

Blanchard, O. and J. Tirole (2004), "The Optimal Design of Unemployment Insurance and Employment Protection. A First Pass", Massachusetts Institute of Technology, mimeo.

Boeri, T. (1999), "Enforcement of Employment Security Regulations, On-the-job Search and Unemployment Duration", European Economic Review, Vol.43, pp.65-89.

Boeri, T., G. Nicoletti and S. Scarpetta (2000), "Regulation and Labour Market Performance", CEPR Discussion Paper Series, No.2420.

Boeri, T., J.I. Conde-Ruiz, and V. Galasso, (2003), "Protecting Against Labour Market Risk: Employment Protection or Unemployment Benefits?", CEPR Discussion Paper \# 3990. 
Brandt, N., J-M. Burniaux and R. Duval (2005), “Assessing the OECD Jobs Strategy: Past Developments and Reforms", OECD Economics Department Working Papers, No.429.

Bruno, M. and J. Sachs (1985), The Economics of Worldwide Stagflation, Basil Blackwell, Oxford.

Buti, M., L.R. Pench and P. Sestito (1998), "European Unemployment: Contending Theories and Institutional Complexities", Economic and Financial Reports, BEI/EIB, Report 98/01.

Calmfors, L., E. J. Driffill (1988): “Centralization of Wage Bargaining”, Economic Policy,3(April).

Calmfors, L. and H. Lang, (1995), 'Macroeconomic Effects of Active Labour Market Programmes In A Union Wage-Setting Model', Economic Journal, 105, pp.601-619.

Conway, P., V. Janod and G. Nicoletti (2005), "Product Market Regulation in OECD Countries: 1998 to 2003”, OECD Economics Department Working Papers, No.419.

Conway, P. and G. Nicoletti (2006), "Product Market Regulation in the Non-Manufacturing Sectors of OECD Countries (1975-2003): Measurement and Highlights", OECD Economics Department Working Papers, forthcoming.

Daveri, F. and G. Tabellini (2000): “Unemployment and Taxes”, Economic Policy, 30 (April).

Davis, S. and M. Henrekson (2004), "Tax effects on Work Activity, Industry Mix and Shadow Economy Size: Evidence from Rich-Country Comparisons", NBER Working Papers, No.10509.

Duval, R. (2003), "The Retirement Effects of Old-Age Pension Systems and Other Social Transfer Programmes in OECD Countries", OECD Economics Department Working Papers, No.370.

Ebell, M. and C. Haefke (2003), "Product Market Deregulation and Labour Market Outcomes", IZA Discussion Paper, No.957.

Ebell, M. and C. Haefke (2004), "The Missing Link: Product Market Regulation, Collective Bargaining and the European Unemployment Puzzle", mimeo, Universitad Pompeu Fabra.

Elmeskov, J., J.P. Martin, and S. Scarpetta, (1998), "Key Lessons for Labour Market Reforms: Evidence from OECD Countries' Experience", Swedish Economic Policy Review, Vol 5, No 2, 1998.

Faini, R., J. Haskel, G. Barba Navaretti, C. Scarpa, C. Wey (2005), "Contrasting Europe's Decline: Do Product Market Reforms Help?" in Structural Reforms Without Prejudice, Boeri, T., M.Castanheira, R.Faini, V.Galasso (eds.), Oxford University Press, forthcoming.

Flanagan, R. (1998), "Macroeconomic Performance and Collective Bargaining: An International Perspective,", GSB Research Paper \#1542, December .

Galasso, V., S. Carcillo, M. Castanheira, G. Nicoletti, E. Perotti, L. Tsyganok (2005), "How to Win Political Support to Reforms?", in Structural reforms without prejudice, Boeri, T., M.Castanheira, R.Faini, V.Galasso (eds.), Oxford University Press, forthcoming.

Griffith, r. and R. Harrison (2004), "The Link Between Product Market Reform and Macro-Economic Performance", European Economy Economic Papers, No.209 (August) 
Heckman, J.J. and C. Pages (2000), "The Cost of Job Security Regulation: Evidence From Latin American Labor Markets", NBER Working Papers, No.7773.

Hicks, J. (1935), “Annual Survey of Economic Theory: the Theory of Monopoly”, Econometrica, Vol.3, pp.1-20.

Holmlund, B. (1997): "Macroeconomic Implications of Cash Limits in the Public Sector", Economica, Vol.64.

Holmlund, B. and J. Lindén (1993), "Job Matching, Temporary Public Employment, and Equilibrium Unemployment.", Journal of Public Economics, Vol.51, pp.329-343.

Jackman, R., R. Layard, and S. Nickell, (1991), Unemployment. Macroeconomic Performance and the Labour Market, Oxford University Press.

Jackman, R., R. Layard, and S. Nickell, (1996), “Combating Unemployment: Is Flexibility Enough”, Centre for Economic Performance Discussion Paper No.293.

Jean, S. and G. Nicoletti, (2004), "Regulation and Wage Premia", GEP Research Paper 04/26, Leverhulme Centre for Research on Globalisation and Economic Policy, University of Nottingham

Koeniger, W. and A. Vindigni (2003), "Employment Protection and Product Market Regulation”, IZA Discussion Paper Series, 880.

Kornai, J., E. Maskin and G. Roland (2003), “Understanding the Soft Budget Constraint”, Journal of Economic Literature, Vol.41, No.4, November.

Koskela, E. (2001), “Labour Taxation and Employment in Trade Union Models: A Partial Survey”, Bank of Finland Discussion Papers, 19.

Krueger, A. and J.-S. Pischke, (1997), "Observations and Conjectures on the U.S. Employment Miracle", NBER Working Paper, No.6146.

Kugler, A., and G. Pica, 2003. "Effects of Employment Protection and Product Market Regulations on the Italian Labor Market." Institute for the Study of Labor, Discussion Paper 948. Bonn, Germany.

Layard, R. and S. Nickell (1998), "Labour Market Institutions and Economic Performance", Centre for Economic Performance, Discussion Paper No.407, September. Forthcoming in the Handbook of Labor Economics, Vol.3.

Lindbeck, A., and D.J. Snower, (1988), The Insider-Outsider Theory of Employment and Unemployment, MIT Press, Cambridge, Massachusetts.

Malley, J. and T. Moutos, (1996), "Does Government Employment "Crowd-Out" Private Employment? Evidence from Sweden," Scandinavian Journal of Economics, Blackwell Publishing, Vol.98(2), pp.289-302, June.

Martin, J. (1996), "Measures of Replacement Rates for the Purpose of International Comparisons", OECD Economics Studies, No.26.

Messina, J. (2005), "Institutions and Service Employment: A Panel Study for OECD Countries" , Labour, CEIS, Fondazione Giacomo Brodolini and Blackwell Publishing Ltd, vol.19(2), pp.343-372. 


\section{ECO/WKP(2005)59}

Mortensen, D. and C. Pissarides, (1999), "Job Reallocation, Employment Fluctuations and Unemployment," CEP Discussion Papers 0421, Centre For Economic Performance, LSE.

Moulton, B. R. (1986), "Random Group Effects and the Precision of Regression Estimates," Journal of Econometrics, pp.385-397.

Nickell, S. (1997), "Unemployment and Labor Market Rigidities: Europe versus North America”, Journal of Economic Perspectives, Vol.11, No.3, Summer, pp.55-74.

Nickell, S. (1999), "Product Markets and Labour Markets”, Labour Economics, Vol.6.

Nickell, S. (2004), "Employment and Taxes", Center for Economic Performance Discussion Paper, No.634, London School of Economics.

Nickell, S., L. Nunziata, W. Ochel and G. Quintini (2003), 'The Beveridge Curve, Unemployment and Wages in the OECD', in P. Aghion, R. Frydman, J. Stiglitz and M. Woodford (eds.) "Knowledge, Information and Expectations in Modern Macroeconomics: in Honor of Edmund S. Phelps", Princeton University Press.

Nicoletti, G., S. Scarpetta and O. Boylaud (1999), "Summary Indicators of Product Market Regulation with an Extension to Employment Protection Legislation", OECD Economics Department Working Papers, No.226.

Nicoletti, G. R.C.G. Haffner, S. Nickell, S. Scarpetta and G. Zoega (2001), "European Integration, Liberalization and Labor_Market Performance”, in G. Bertola, T. Boeri and G. Nicoletti (eds.) (2001) "Welfare and Employment in United Europe", the MIT Press, Cambridge Mass.

Nicoletti, G. and S. Scarpetta (2003), "Regulation, Productivity and Growth: OECD Evidence”, Economic Policy, 36 (April).

OECD (1994a), The OECD Jobs Study: Facts, Analysis, and Strategies, Paris.

OECD (1994b), The OECD Jobs Study, Evidence and Explorations, Part II, Paris.

OECD (1999a), Employment Outlook, Paris.

OECD (1999b), Implementing the OECD Jobs Strategy: Assessing Performance and Policy, Paris.

OECD (2001), OECD Economic Studies,No.32, Special Issue on Regulatory Reform.

OECD (2004), Employment Outlook, Paris.

OECD (2005), "Product Market Regulation and Productivity Growth", ECO/CPE/WP1(2005)16

Office of Management and Budget, (1998), US Office of Information and Regulatory Affairs, Draft Report to Congress on the Cost and Benefits of Federal Regulations

Piore, M. (1986), “Labor Market Flexibility”, University of California, Berkeley, CA.

Pischke, J.S. (2002), "Comments on Cahuc and Zylberberg - Public Employment: Does it Increase Unemployment?", Economic Policy, No.34. 
Pissarides, C.A. (2001a), "Company Start-Up Costs and Employment”, Center for Economic Performance Discussion Paper, No. 520, London School of Economics.

Pissarides, C.A. (2001b), “Employment Protection”, Labour Economics, 8, 131-59.

Prescott, E.G. (2004), "Why do Americans Work so Much More than Europeans?," NBER Working Papers 10316, National Bureau of Economic Research, Inc.

Saint Paul, G. (1996), "Dual Labour Markets”, The MIT Press, Cambridge Massachusetts.

Sappington, D.E. and J.G. Sidak (2003), "Incentives for Anticompetitive Behaviour by Public Enterprises", Review of Industrial Organization, Vol.22, pp.183-206.

Scarpetta, S. (1996), “Assessing the Role of Labour Market Policies and Institutional Settings on Unemployment: A Cross-Country Study”, OECD Economic Studies, No.26, 1996/1.

Spector, D. (2002), "Competition and the Capital-Labour Conflict", CEPREMAP Working Papers, 0207 
Annex Table 1. Regressions without public employment

\begin{tabular}{|c|c|c|c|c|}
\hline & \multicolumn{4}{|c|}{ Non-agricultural business employment rate } \\
\hline & \multicolumn{2}{|c|}{$\begin{array}{l}\text { Without pub. emp. \& interactions, } \\
\text { robust }\end{array}$} & \multicolumn{2}{|c|}{$\begin{array}{c}\text { Without pub. emp. \& interactions, } \\
\text { robust }\end{array}$} \\
\hline & & $\begin{array}{l}\text { ith control for } \\
\text { outliers }\end{array}$ & & $\begin{array}{l}\text { With control for } \\
\text { outliers }\end{array}$ \\
\hline Constant & $\begin{array}{c}45.447 \\
(1.669)^{\star \star \star}\end{array}$ & $\begin{array}{c}45.13 \\
(1.604)^{\star \star \star}\end{array}$ & $\begin{array}{c}46.711 \\
(1.792)^{\star \star \star}\end{array}$ & $\begin{array}{c}46.498 \\
(1.758)^{\star \star \star}\end{array}$ \\
\hline Output gap & $\begin{array}{c}0.448 \\
(0.030)^{\star \star \star}\end{array}$ & $\begin{array}{c}0.451 \\
(0.028)^{\star \star \star}\end{array}$ & $\begin{array}{c}0.454 \\
(0.033)^{\star \star *}\end{array}$ & $\begin{array}{c}0.455 \\
(0.030)^{\star \star \star}\end{array}$ \\
\hline LM institutions & $\begin{array}{c}-0.978 \\
(0.398)^{\star \star}\end{array}$ & $\begin{array}{c}-1.012 \\
(0.408)^{\star \star}\end{array}$ & $\begin{array}{c}-1.007 \\
(0.394)^{\star *}\end{array}$ & $\begin{array}{c}-1.017 \\
(0.401)^{\star *}\end{array}$ \\
\hline LM policies & $\begin{array}{c}-2.178 \\
(0.698)^{\star \star \star}\end{array}$ & $\begin{array}{c}-2.001 \\
(0.647)^{\star \star \star}\end{array}$ & & \\
\hline PM regulation & & & $\begin{array}{l}-0.409 \\
(0.248)^{\star}\end{array}$ & $\begin{array}{l}-0.316 \\
-0.24\end{array}$ \\
\hline PM reg. in high LMR & $\begin{array}{c}-0.587 \\
(0.241)^{\star \star}\end{array}$ & $\begin{array}{c}-0.492 \\
(0.232)^{\star \star}\end{array}$ & & \\
\hline PM reg. in med. LMR & $\begin{array}{l}-0.324 \\
-0.252\end{array}$ & $\begin{array}{l}-0.262 \\
-0.244\end{array}$ & & \\
\hline PM reg. in low LMR & $\begin{array}{r}0.198 \\
-0.258\end{array}$ & $\begin{array}{r}0.315 \\
-0.251\end{array}$ & & \\
\hline LM pol. in high PMR & & & $\begin{array}{c}-3.276 \\
(0.710)^{\star \star \star}\end{array}$ & $\begin{array}{c}-3.245 \\
(0.672)^{\star \star \star}\end{array}$ \\
\hline LM pol. in med. PMR & & & $\begin{array}{c}-3.613 \\
(0.743)^{\star \star \star}\end{array}$ & $\begin{array}{c}-3.544 \\
(0.733)^{\star \star \star}\end{array}$ \\
\hline LM pol. in low PMR & & & $\begin{array}{c}-3.961 \\
(0.717)^{\star \star \star}\end{array}$ & $\begin{array}{c}-4.236 \\
(0.666)^{\star \star \star}\end{array}$ \\
\hline $\begin{array}{l}\text { Country fixed effects } \\
\text { Country-specific time trends } \\
\text { Observations } \\
\text { Number of countries } \\
\text { R-squared } \\
\end{array}$ & $\begin{array}{c}\text { yes } \\
\text { yes } \\
445 \\
20 \\
0.86 \\
\end{array}$ & $\begin{array}{c}\text { yes } \\
\text { yes } \\
431 \\
20 \\
0.88 \\
\end{array}$ & $\begin{array}{c}\text { yes } \\
\text { yes } \\
445 \\
20 \\
0.85 \\
\end{array}$ & $\begin{array}{c}\text { yes } \\
\text { yes } \\
432 \\
20 \\
0.87 \\
\end{array}$ \\
\hline
\end{tabular}

Standard errors in parentheses

${ }^{*}$ significant at $10 \%$; ${ }^{* *}$ significant at $5 \%$; ${ }^{* *}$ significant at $1 \%$ 
Annex Figure 1. Sensitivity analysis by country

(coefficients and confidence intervals at $5 \%$ level)

\section{Product market regulations in countries with stricter labor market regulations and policies}

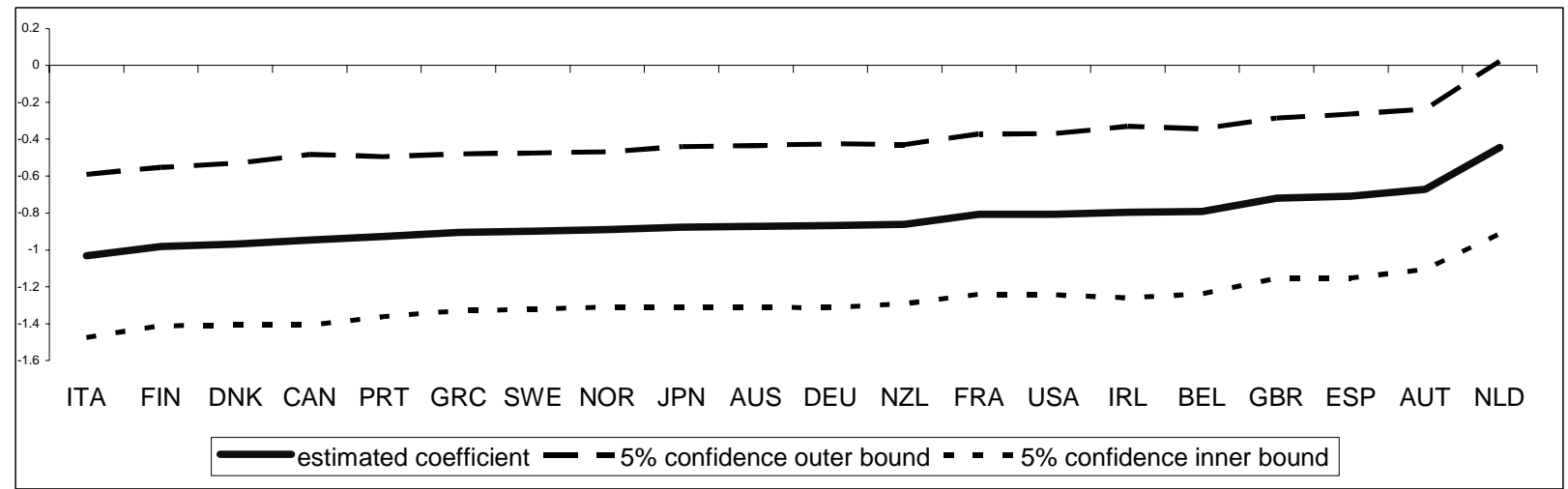

Labor market institutions, synthetic indicator

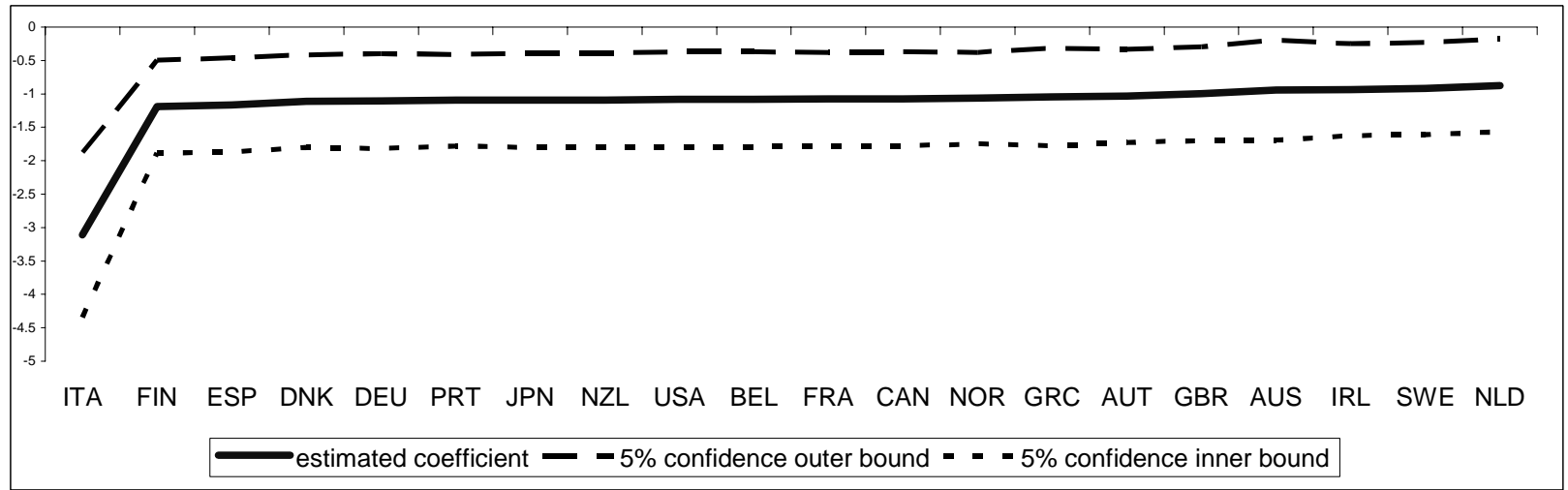

Labor market policy, synthetic indicator

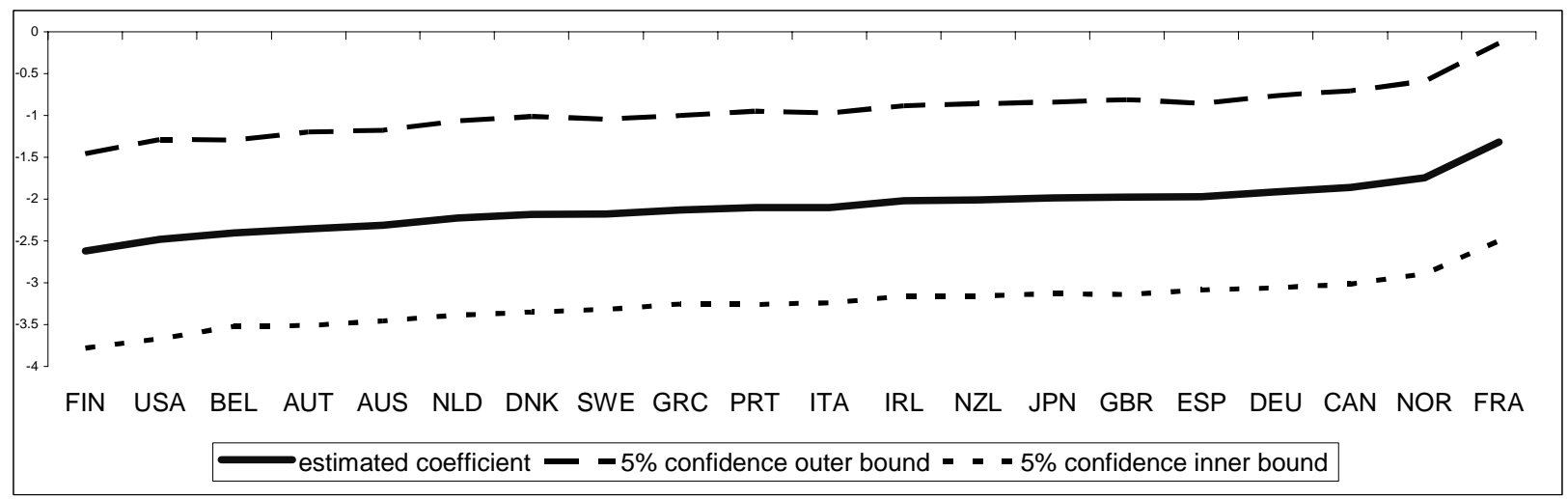

The reported coefficients for product market regulations are those in countries with more protective and costly labour market policies ; see column 2 in Table 4. 
Annex Table 2: Main characteristics of the panel dataset

\begin{tabular}{|c|c|c|c|c|c|c|}
\hline Variable & & Mean & Std. Dev. & Min & Max & Observations \\
\hline $\begin{array}{l}\text { Non-agricultural business } \\
\text { employment rate }\end{array}$ & $\begin{array}{l}\text { overall } \\
\text { between } \\
\text { within }\end{array}$ & 0.48 & $\begin{array}{l}0.07 \\
0.06 \\
0.03\end{array}$ & $\begin{array}{l}0.32 \\
0.36 \\
0.40\end{array}$ & $\begin{array}{l}0.65 \\
0.60 \\
0.62\end{array}$ & $\begin{array}{ll}\mathrm{N}= & 553 \\
\mathrm{n}= & 20 \\
\mathrm{~T}= & 28\end{array}$ \\
\hline Public employment rate & $\begin{array}{l}\text { overall } \\
\text { between } \\
\text { within }\end{array}$ & 0.12 & $\begin{array}{l}0.05 \\
0.05 \\
0.01\end{array}$ & $\begin{array}{l}0.04 \\
0.06 \\
0.07\end{array}$ & $\begin{array}{l}0.26 \\
0.24 \\
0.16\end{array}$ & $\begin{array}{ll}\mathrm{N}= & 520 \\
\mathrm{n}= & 20 \\
\mathrm{~T}= & 26\end{array}$ \\
\hline Union density & $\begin{array}{l}\text { overall } \\
\text { between } \\
\text { within }\end{array}$ & 42.45 & $\begin{array}{c}20.88 \\
19.43 \\
8.72\end{array}$ & $\begin{array}{c}8.60 \\
12.44 \\
18.57\end{array}$ & $\begin{array}{l}88.60 \\
80.91 \\
82.79\end{array}$ & $\begin{array}{ll}\mathrm{N}= & 588 \\
\mathrm{n}= & 21 \\
\mathrm{~T}= & 28\end{array}$ \\
\hline Index of corporatism & $\begin{array}{l}\text { overall } \\
\text { between } \\
\text { within }\end{array}$ & 2.04 & $\begin{array}{l}0.91 \\
0.80 \\
0.46\end{array}$ & $\begin{array}{l}1.00 \\
1.00 \\
0.79\end{array}$ & $\begin{array}{l}3.00 \\
3.00 \\
2.97\end{array}$ & $\begin{array}{ll}\mathrm{N}= & 588 \\
\mathrm{n}= & 21 \\
\mathrm{~T}= & 28\end{array}$ \\
\hline $\begin{array}{l}\text { Labour market institutions } \\
\text { (principal component) }\end{array}$ & $\begin{array}{l}\text { overall } \\
\text { between } \\
\text { within }\end{array}$ & 0.00 & $\begin{array}{l}0.80 \\
0.74 \\
0.35\end{array}$ & $\begin{array}{l}-1.44 \\
-1.41 \\
-0.89\end{array}$ & $\begin{array}{l}1.52 \\
1.45 \\
1.27\end{array}$ & $\begin{array}{ll}\mathrm{N}= & 588 \\
\mathrm{n}= & 21 \\
\mathrm{~T}= & 28\end{array}$ \\
\hline $\begin{array}{l}\text { Unemployment benefit } \\
\text { generosity }\end{array}$ & $\begin{array}{l}\text { overall } \\
\text { between } \\
\text { within }\end{array}$ & 27.90 & $\begin{array}{c}13.43 \\
12.53 \\
5.51\end{array}$ & $\begin{array}{l}0.35 \\
5.07 \\
2.01\end{array}$ & $\begin{array}{l}68.50 \\
58.22 \\
46.94\end{array}$ & $\begin{array}{ll}\mathrm{N}= & 588 \\
\mathrm{n}= & 21 \\
\mathrm{~T}= & 28\end{array}$ \\
\hline Tax wedge & $\begin{array}{l}\text { overall } \\
\text { between } \\
\text { within }\end{array}$ & 28.54 & $\begin{array}{l}8.98 \\
8.62 \\
3.06\end{array}$ & $\begin{array}{c}8.96 \\
14.76 \\
12.20\end{array}$ & $\begin{array}{l}45.55 \\
42.41 \\
36.23\end{array}$ & $\begin{array}{l}\mathrm{N}=\quad 580 \\
\mathrm{n}=\quad 21 \\
\mathrm{~T} \text {-bar }=27.6\end{array}$ \\
\hline $\begin{array}{l}\text { Employment protection } \\
\text { legislation }\end{array}$ & $\begin{array}{l}\text { overall } \\
\text { between } \\
\text { within }\end{array}$ & 2.18 & $\begin{array}{l}1.13 \\
1.12 \\
0.27\end{array}$ & $\begin{array}{l}0.20 \\
0.20 \\
0.97\end{array}$ & $\begin{array}{l}4.10 \\
3.92 \\
2.74\end{array}$ & $\begin{array}{l}\mathrm{N}=\quad 433 \\
\mathrm{n}=\quad 21 \\
\mathrm{~T} \text {-bar }=20.6\end{array}$ \\
\hline $\begin{array}{l}\text { Labour market policies } \\
\text { (principal component }\end{array}$ & $\begin{array}{l}\text { overall } \\
\text { between } \\
\text { within }\end{array}$ & 0.00 & $\begin{array}{l}0.80 \\
0.80 \\
0.19\end{array}$ & $\begin{array}{l}-1.52 \\
-1.21 \\
-0.90\end{array}$ & $\begin{array}{l}1.35 \\
0.96 \\
0.39\end{array}$ & $\begin{array}{l}\mathrm{N}=433 \\
\mathrm{n}=\quad 21 \\
\mathrm{~T} \text {-bar }=20.6\end{array}$ \\
\hline $\begin{array}{l}\text { Product market regulation } \\
\text { manufacturing) }\end{array}$ & $\begin{array}{l}\text { overall } \\
\text { between } \\
\text { within }\end{array}$ & 3.96 & $\begin{array}{l}1.29 \\
0.81 \\
1.02\end{array}$ & $\begin{array}{l}0.95 \\
2.22 \\
1.50\end{array}$ & $\begin{array}{l}6.00 \\
5.26 \\
6.09\end{array}$ & $\begin{array}{l}\mathrm{N}=488 \\
\mathrm{n}=\quad 21 \\
\text { T-bar }=23.2\end{array}$ \\
\hline Output gap & $\begin{array}{l}\text { overall } \\
\text { between } \\
\text { within }\end{array}$ & -0.44 & $\begin{array}{l}2.64 \\
0.68 \\
2.55\end{array}$ & $\begin{array}{c}-11.22 \\
-1.81 \\
-10.16\end{array}$ & $\begin{array}{l}7.22 \\
0.92 \\
7.30\end{array}$ & $\begin{array}{l}\mathrm{N}=\quad 555 \\
\mathrm{n}= \\
\mathrm{T} \text {-bar }=21 \\
=2.4\end{array}$ \\
\hline
\end{tabular}




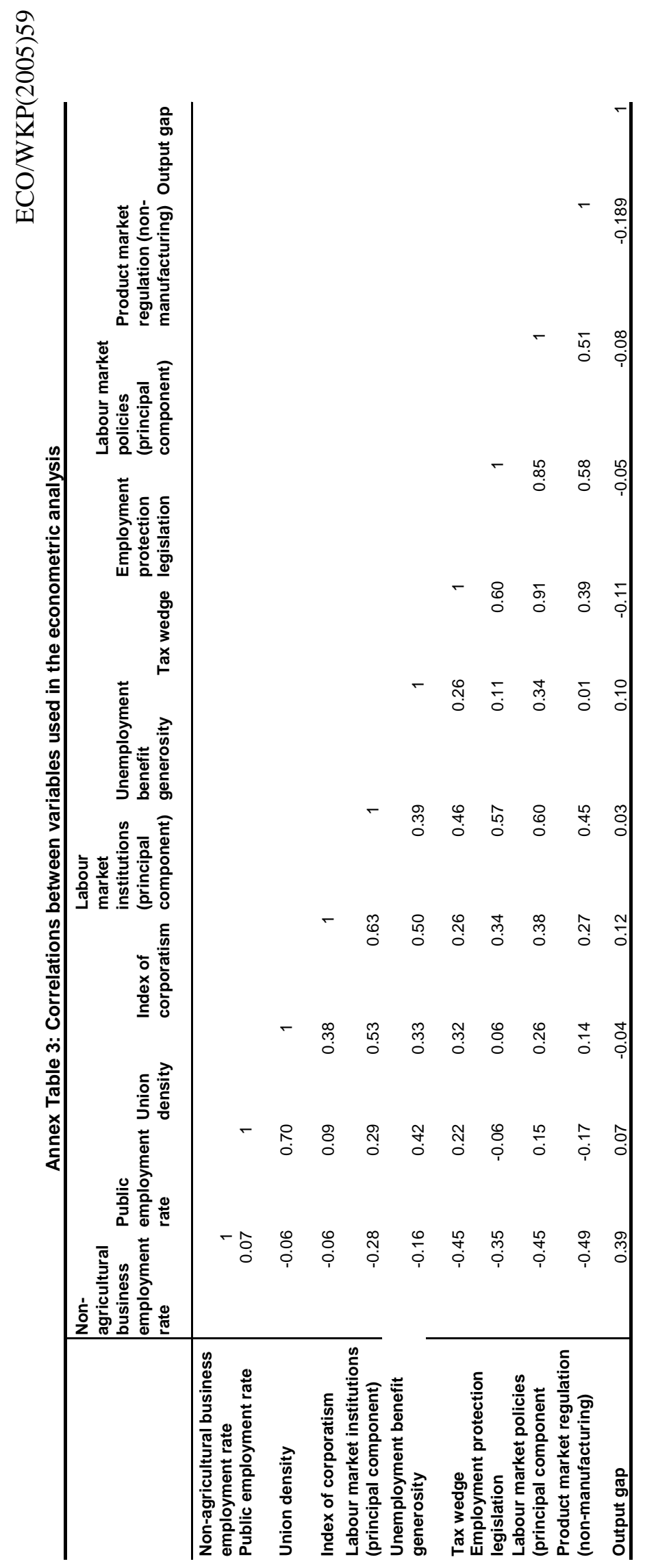




\section{Annex Table 4: Construction of the indicators of product market regulation}

The indicators of regulatory conditions in the seven non-manufacturing sectors are calculated according to the following tables. the indicators.

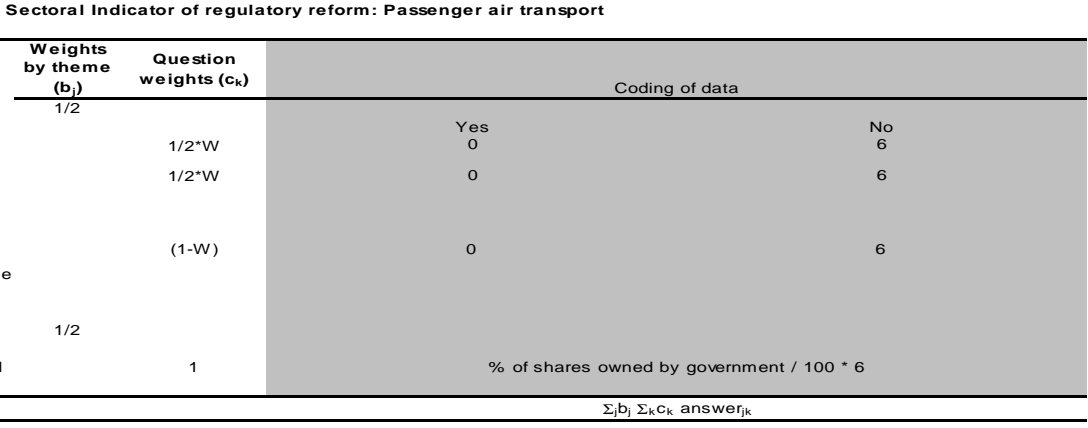

Entry regulation: the United States?

Is your country participating in a regional agreement?

Is the domestic aviation market in your country fully liberalised? That is, there are no restrictions on the number of (domestic) aillines no restre allowed to operate

Public ownership:
What percentage of shares in the largest carrie (domestic and international traffic combined) are owned $\frac{\text { by national, state or provincial authorities? }}{\text { Country scores (0-6) }}$ $\Sigma_{\mathrm{j}} \mathrm{b}_{\mathrm{j}} \Sigma_{\mathrm{k}} \mathrm{C}_{\mathrm{k}}$ answer $\mathrm{r}_{\mathrm{ik}}$

Notes: the weight $W$ is the average share of international traffic in total traffic (measured in '000 rpk's) in the OECD.

Sectoral Indicator of regulatory reform: Telecom

\begin{tabular}{|c|c|c|c|c|c|}
\hline \multirow[b]{2}{*}{ Entry regulation: } & $\begin{array}{l}\text { Weights } \\
\text { by theme } \\
\left(b_{j}\right)\end{array}$ & $\begin{array}{c}\text { Question } \\
\text { weights }\left(c_{k}\right)^{1}\end{array}$ & \multicolumn{3}{|c|}{ Coding of data } \\
\hline & & & Free entry & Franchised to 2 or more firms & Franchised to 1 firm \\
\hline $\begin{array}{l}\text { What are the legal conditions of entry into the trunk } \\
\text { telephony market? }\end{array}$ & & $1 / 4^{\star} w^{t \star}\left(1-w^{m}\right)$ & 0 & 3 & 6 \\
\hline $\begin{array}{l}\text { What are the legal conditions of entry into the } \\
\text { international market? }\end{array}$ & & $1 / 4^{*}\left(1-w^{t}\right)\left(1-w^{m}\right)$ & 0 & 3 & 6 \\
\hline $\begin{array}{l}\text { What are the legal conditions of entry into the mobile } \\
\text { market? }\end{array}$ & & $1 / 2^{*} w^{m}$ & 0 & 3 & 6 \\
\hline Public ownership: & $1 / 4$ & & & & \\
\hline $\begin{array}{l}\text { What percentage of shares in the PTO are owned by } \\
\text { government? }\end{array}$ & & $1-\mathrm{w}_{\mathrm{m}}$ & & $\%$ government ownership / $100 * 6$ & \\
\hline $\begin{array}{l}\text { What percentage of shares in the largest firm in the } \\
\text { mobile telecommunications sector are owned by } \\
\text { government? }\end{array}$ & & $\mathrm{w} \mathrm{m}$ & & $\%$ government ownership / $100 * 6$ & \\
\hline Market structure $:^{3}$ & $1 / 4$ & & & & \\
\hline $\begin{array}{l}\text { What is the market share of new entrants in the trunk } \\
\text { telephony market? }\end{array}$ & & $1 / 4^{*} w^{t *}\left(1-w^{m}\right)$ & & 6-normalised market share ${ }^{2}$ & \\
\hline $\begin{array}{l}\text { What is the market share of new entrants in the } \\
\text { international telephony market? }\end{array}$ & & $1 / 4^{*}\left(1-w^{t}\right)\left(1-w^{m}\right)$ & & 6-normalised market share & \\
\hline $\begin{array}{l}\text { What is the market share of new entrants in the mobile } \\
\text { market? }\end{array}$ & & $1 / 2^{*} w^{m}$ & & 6-normalised market share & \\
\hline Country scores (0-6) & & & & $\Sigma_{\mathrm{j}} \mathrm{b}_{\mathrm{j}} \Sigma_{\mathrm{k}} \mathrm{c}_{\mathrm{k}}$ answer $\mathrm{r}_{\mathrm{j} k}$ & \\
\hline
\end{tabular}
Country scores $(0-6)$

1 The weight $w_{m}$ is the OECD-wide revenue share from mobile telephony in total revenue from trunk, international, and mobile. The weight $w^{t}$ is the OECD-wide revenue share of trunk in total revenue from trunk and international telephony.

3 For the purposes of calculating the indicator the market share of new entrants has been normalised to be between 0 and 6 with 6 being the smallest market share over al countries and time and 0 being the largest.

Sectoral Indicator of regulatory reform: Electricity

Entry regulation:

How are the terms and conditions of third party access
(TPA) to the electricity transmission grid determined? Is there a liberalised wholesale market for electricity (a

What is the minimum consumption threshold that consumers must exceed in order to be able to choose Their electricity supplier?

Public ownership:

What is the ownership structure of the larges companies in the generation, transmission, distribution Vertical Integration

What is the degree of vertical separation between the transmission and generation segments of the electricity industry?

What is the overall degree of vertical integration in the electricity industry?

\begin{tabular}{|c|c|c|c|c|c|c|c|}
\hline $\begin{array}{l}\text { Weights } \\
\text { by theme } \\
\left(b_{j}\right)\end{array}$ & $\begin{array}{c}\text { Question } \\
\text { weights }\left(c_{k}\right)\end{array}$ & \multicolumn{6}{|c|}{ Coding of data } \\
\hline \multirow[t]{6}{*}{$1 / 3$} & & \multicolumn{2}{|c|}{ Regulated TPA } & \multicolumn{2}{|c|}{ Negotiated TPA } & \multicolumn{2}{|c|}{ No TPA } \\
\hline & $1 / 3$ & \multicolumn{2}{|c|}{0} & \multicolumn{2}{|c|}{3} & \multicolumn{2}{|c|}{6} \\
\hline & \multirow{3}{*}{$1 / 3$} & & yes & \multicolumn{4}{|c|}{ no } \\
\hline & & & 0 & & & 6 & \\
\hline & & No threshold & $\begin{array}{l}<250 \\
\text { gigawatts }\end{array}$ & $\begin{array}{l}\text { Between } 250 \\
\text { and } 500 \\
\text { gigawatts }\end{array}$ & $\begin{array}{l}\text { Between } 500 \\
\text { and } 1000 \\
\text { gigawatts }\end{array}$ & $\begin{array}{c}\text { More than } \\
1000 \\
\text { gigawatts }\end{array}$ & $\begin{array}{l}\text { No consumer } \\
\text { choice }\end{array}$ \\
\hline & \multirow[t]{2}{*}{$1 / 3$} & 0 & 1 & 2 & 3 & 4 & 6 \\
\hline \multirow[t]{2}{*}{$1 / 3$} & & Private & Mostly Private & Mixed & Mostly Public & \multicolumn{2}{|c|}{ Public } \\
\hline & \multirow[t]{2}{*}{1} & 0 & 1.5 & 3 & 4.5 & \multicolumn{2}{|c|}{6} \\
\hline \multirow[t]{4}{*}{$1 / 3$} & & \multicolumn{2}{|c|}{ Separate Companies } & \multicolumn{2}{|c|}{ Accounting separation } & \multicolumn{2}{|c|}{ Integrated } \\
\hline & \multirow[t]{2}{*}{$1 / 2$} & \multicolumn{2}{|c|}{0} & \multicolumn{2}{|c|}{3} & \multicolumn{2}{|c|}{6} \\
\hline & & \multicolumn{2}{|c|}{ Unbundled } & \multicolumn{2}{|c|}{ Mixed } & \multicolumn{2}{|c|}{ Integrated } \\
\hline & $1 / 2$ & \multicolumn{2}{|c|}{0} & \multicolumn{2}{|c|}{3} & \multicolumn{2}{|c|}{6} \\
\hline
\end{tabular}

$\Sigma_{\mathrm{j}} \mathrm{b}_{i} \Sigma_{\mathrm{k}} \mathrm{C}_{\mathrm{k}}$ answer $\mathrm{r}_{\mathrm{ik}}$ 
ECO/WKP(2005)59

\begin{tabular}{|c|c|c|c|c|c|}
\hline \multirow{2}{*}{ Entry regulation: } & $\begin{array}{c}\text { Weights } \\
\text { by theme } \\
\left(b_{j}\right)\end{array}$ & $\begin{array}{c}\text { Question } \\
\text { weights }\left(c_{k}\right)\end{array}$ & \multicolumn{3}{|c|}{ Coding of data } \\
\hline & & & Regulated TPA & Negotiated TPA & No TPA \\
\hline $\begin{array}{l}\text { How are the terms and conditions of third party access } \\
\text { (TPA) to the gas transmission grid determined? }\end{array}$ & & $1 / 3$ & 0 & 3 & 6 \\
\hline What percentage of the retail market is open to & & $1 / 3$ & \multicolumn{3}{|c|}{ (1-\% of market open to choice $/ 100)^{*} 6$} \\
\hline & & & No, free entry in all markets & Yes, in some markets & Yes, in all markets \\
\hline $\begin{array}{l}\text { Do national, state or provincial laws or other regulations } \\
\text { restrict the number of competitors allowed to operate a } \\
\text { business in at least some markets in the sector: gas } \\
\text { production/import }\end{array}$ & & $1 / 3$ & o & 3 & 6 \\
\hline Public ownership: & $1 / 4$ & & None & Between 0 and $100 \%$ & $100 \%$ \\
\hline $\begin{array}{l}\text { What percentage of shares in the largest firm in the gas } \\
\text { production/import sector are owned by government? }\end{array}$ & & $1 / 3$ & o & 3 & 6 \\
\hline $\begin{array}{l}\text { What percentage of shares in the largest firm in the gas } \\
\text { transmission sector are owned by government? }\end{array}$ & & $1 / 3$ & o & 3 & 6 \\
\hline $\begin{array}{l}\text { What percentage of shares in the largest firm in the gas } \\
\text { distribution sector are owned by government? }\end{array}$ & & $1 / 3$ & o & 3 & 6 \\
\hline Vertical Integration: & $1 / 4$ & & & Legal/Accounting separation & Integrated \\
\hline $\begin{array}{l}\text { What is the degree of vertical separation between gas } \\
\text { production/import and the other segments of the } \\
\text { industry? }\end{array}$ & & $1 / 2$ & o & 3 & 6 \\
\hline $\begin{array}{l}\text { What is the degree of vertical separation between gas } \\
\text { supply and the other segments of the industry? }\end{array}$ & & $3 / 10$ & 0 & 3 & 6 \\
\hline Is gas distribution vertically separate from gas supply? & & $1 / 5$ & o & 3 & 6 \\
\hline Market structure: & 1/4 & & $<50 \%$ & between 50 and $90 \%$ & $>90 \%$ \\
\hline $\begin{array}{l}\text { What is the market share of the largest company in the } \\
\text { gas production/import industry? }\end{array}$ & & $1 / 3$ & 0 & 3 & 6 \\
\hline $\begin{array}{l}\text { What is the market share of the largest company in the } \\
\text { gas transmission industry? }\end{array}$ & & $1 / 3$ & o & 3 & 6 \\
\hline $\begin{array}{l}\text { What is the market share of the largest company in the } \\
\text { gas supply industry? }\end{array}$ & & $1 / 3$ & o & 3 & 6 \\
\hline
\end{tabular}

\begin{tabular}{|c|c|c|c|c|c|}
\hline \multirow{2}{*}{ Entry regulation: } & \multirow{2}{*}{$\begin{array}{c}\begin{array}{c}\text { Weights } \\
\text { by theme } \\
\left(\mathbf{b}_{\mathrm{j}}\right)\end{array} \\
1 / 2\end{array}$} & \multirow[t]{2}{*}{$\begin{array}{c}\text { Question } \\
\text { weights }\left(c_{k}\right)\end{array}$} & \multicolumn{3}{|c|}{ Coding of data } \\
\hline & & & No, free entry in all markets & Yes, in some markets & Yes, in all markets \\
\hline $\begin{array}{l}\text { Do national, state or provincial laws or other regulations } \\
\text { restrict the number of competitors allowed to operate a } \\
\text { business in at least some markets in the sector: } \\
\text { national post - basic letter services }\end{array}$ & & $1 / 3$ & o & 3 & 6 \\
\hline $\begin{array}{l}\text { Do national, state or provincial laws or other regulations } \\
\text { restrict the number of competitors allowed to operate a } \\
\text { business in at least some markets in the sector: } \\
\text { national post - basic parcel services the }\end{array}$ & & $1 / 3$ & o & 3 & 6 \\
\hline $\begin{array}{l}\text { Do national, state or provincial laws or other regulations } \\
\text { restrict the number of competitors allowed to operate a } \\
\text { business in at least some markets in the sector: courier } \\
\text { activities other than national post }\end{array}$ & & $1 / 3$ & o & & 6 \\
\hline Public ownership: & $1 / 2$ & & & & \\
\hline $\begin{array}{l}\text { What percentage of shares in the largest firm in the } \\
\text { sector: national post - basic letter services are owned } \\
\text { by the government? }\end{array}$ & & $1 / 3$ & $\begin{array}{c}\text { None } \\
\text { o }\end{array}$ & $\begin{array}{c}\text { Between } 0 \text { and } 100 \% \\
3\end{array}$ & $\begin{array}{c}100 \% \\
6\end{array}$ \\
\hline $\begin{array}{l}\text { What percentage of shares in the largest firm in the } \\
\text { sector: national post - basic parcel services are owned } \\
\text { by the government? }\end{array}$ & & $1 / 3$ & o & 3 & 6 \\
\hline & & & No Govt involvement in sector & $\begin{array}{l}\text { Govt. controls at least } 1 \text { firm, } \\
\text { but other firms operate as well }\end{array}$ & $\begin{array}{l}\text { Govt controls all dominant } \\
\text { firms in sector }\end{array}$ \\
\hline $\begin{array}{l}\text { What is the extent of public ownership in the courier } \\
\text { (activities other than national post) sector? }\end{array}$ & & $1 / 3$ & o & 3 & 6 \\
\hline
\end{tabular}

\begin{tabular}{|c|c|c|c|c|c|c|}
\hline \multirow[b]{3}{*}{ Entry regulation: } & \multicolumn{3}{|c|}{ Sectoral Indica tor of regulatory reform: Rail } & & & \\
\hline & $\begin{array}{l}\text { Weights } \\
\text { by theme } \\
\left(b_{j}\right) \\
\end{array}$ & $\begin{array}{c}\text { Question } \\
\text { weights }\left(c_{k}\right)\end{array}$ & \multicolumn{4}{|c|}{ Coding of data } \\
\hline & & & $\begin{array}{l}\text { Free entry (upon paying } \\
\text { access fees) }\end{array}$ & Entry franch & $\begin{array}{l}\text { ed to several } \\
\text { is }\end{array}$ & $\begin{array}{l}\text { Entry franchised to a single } \\
\text { firm or regulated according to } \\
\text { EU } 1991 \text { directive }\end{array}$ \\
\hline $\begin{array}{l}\text { What are the legal conditions of entry into the } \\
\text { passenger transport rail market? }\end{array}$ & & $1 / 2$ & 0 & & & 6 \\
\hline $\begin{array}{l}\text { What are the legal conditions of entry into the freight } \\
\text { transport rail market? }\end{array}$ & & $1 / 2$ & o & & & 6 \\
\hline Public ownership: & $1 / 4$ & & & & & \\
\hline $\begin{array}{l}\text { What percentage of shares in the largest firm in } \\
\text { operation of infrastructure sector is owned by } \\
\text { government? }\end{array}$ & & $1 / 4$ & $\begin{array}{c}\text { No public ownership } \\
0\end{array}$ & Between $\mathrm{C}$ & and $100 \%$ & $\begin{array}{c}100 \% \\
0\end{array}$ \\
\hline $\begin{array}{l}\text { What percentage of shares in the largest firm in } \\
\text { passenger transport sector is owned by government? }\end{array}$ & & $1 / 4$ & o & & & 6 \\
\hline $\begin{array}{l}\text { What percentage of shares in the largest firm in freight } \\
\text { transport sector is owned by government? }\end{array}$ & & $1 / 4$ & no & & & yes \\
\hline $\begin{array}{l}\text { Do national, state or provincial government holds equity } \\
\text { stakes in business company : Railways }\end{array}$ & & $1 / 4$ & o & & & 6 \\
\hline Market structure: & $1 / 4$ & & $>1$ & & & 1 \\
\hline $\begin{array}{l}\text { What is the maximum number of operators that } \\
\text { compete in the same area / rail district in the passenger } \\
\text { transport market? }\end{array}$ & & $1 / 2$ & o & & & 6 \\
\hline $\begin{array}{l}\text { What is the maximum number of operators in the freight } \\
\text { transport market? }\end{array}$ & & $1 / 2$ & o & & & 6 \\
\hline Vertical Separation: & $1 / 4$ & & Ownership separation & $\begin{array}{l}\text { Legal } \\
\text { separation }\end{array}$ & $\begin{array}{l}\text { Accounting } \\
\text { separation }\end{array}$ & No separation \\
\hline $\begin{array}{l}\text { What is the degree of separation between the operation } \\
\text { of intrastructure and the provision of railway services } \\
\text { (the actual transport of passengers or freight)? }\end{array}$ & & 1 & o & 3 & 4.5 & 6 \\
\hline
\end{tabular}




\section{ECO/WKP(2005)59}

Sectoral Indicator of regulatory reform: Road

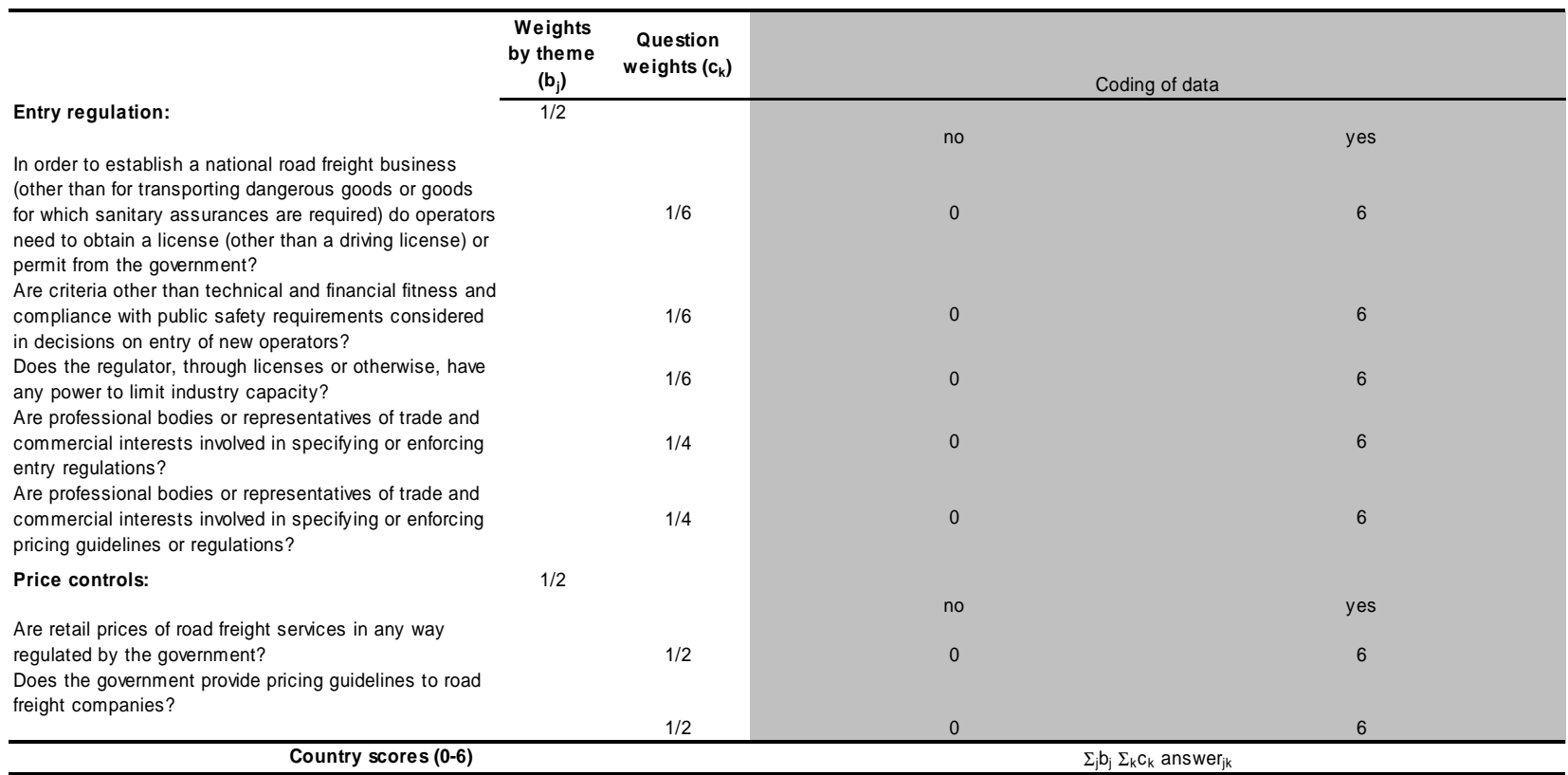


Annex Table 5. Industry-specific time-series indicators of product market regulation (1975-2003): coverage and sources

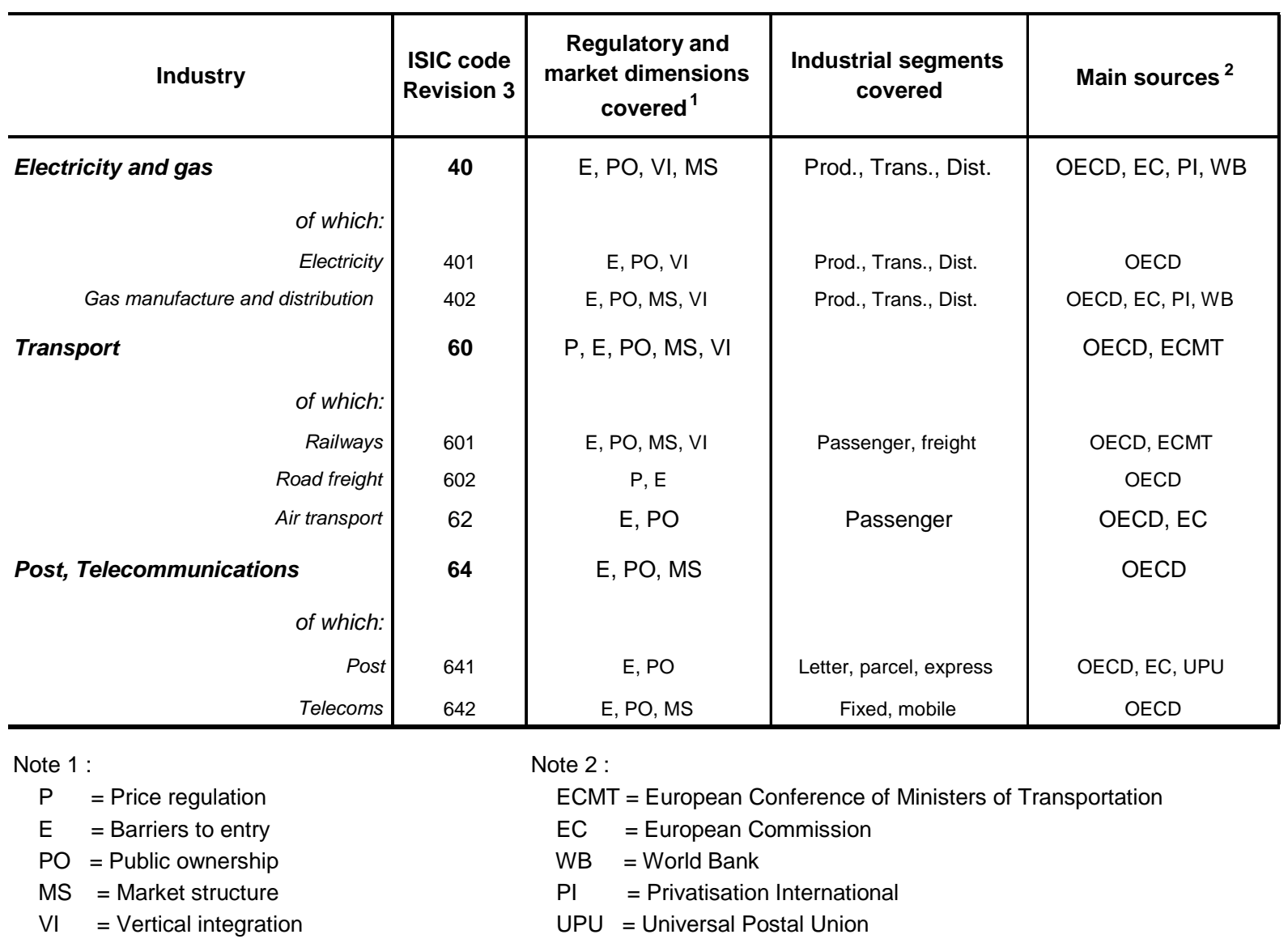




\section{WORKING PAPERS}

The full series of Economics Department Working Papers can be consulted at www.oecd.org/eco/Working_Papers/

471. Fast-falling barriers and growing concentration: the emergence of a private economy in China (December 2005) Sean Dougherty and Richard Herd

470. Sustaining high growth through innovation: reforming the $R \& D$ and education systems in Korea (December 2005) Yongchun Baek and Randall Jones

469. The labour market in Korea: enhancing flexibility and raising participation (December 2005) Randall Jones

468. Getting the most out of public-sector decentralization in Korea (December 2005) Randall Jones and Tadashi Yokoyama

467. Coping with the inevitable adjustment in the US current account (December 2005) Peter Jarrett

466. Is there a case for sophisticated balanced-budget rules? (December 2005) Antonio Fatás

465. Fiscal rules for sub-central governments design and impact (December 2005) Douglas Sutherland, Robert Price and Isabelle Joumard

464. Assessing the robustness of demographic projections in OECD countries (December 2005) Frédéric Gonand

463. The Benefits of Liberalising Product Markets and Reducing Barriers to International Trade and Investment in the OECD

(December 2005)

462. Fiscal relations across levels of government in the United States (November 2005) Thomas Laubach

461. Assessing the value of indicators of underlying inflation for monetary policy (November 2005) Pietro Catte and Torsten Sløk.

460. Regulation and economic performance: product market reforms and productivity in the OECD (November 2005) Giuseppe Nicoletti and Stefano Scarpetta.

459. Innovation in the Business Sector

(November 2005) Florence Jaumotte and Nigel Pain

458. From Innovation Development to Implementation: Evidence from the Community Innovation Survey (November 2005) Florence Jaumotte and Nigel Pain

457. From Ideas to Development: the Determination of $R \& D$ and Patenting (November 2005) Florence Jaumotte and Nigel Pain

456. An Overview of Public Policies to Support Innovation (November 2005) Florence Jaumotte and Nigel Pain

455. Strengthening Regulation in Chile: The Case of Network Industries (November 2005) Alexander Galetovic and Luiz de Mello 
454. Fostering Innovation in Chile

(November 2005) José-Miguel Benavente, Luiz de Mello and Nanno Mulder

453. Getting the most out of public sector decentralisation in Mexico (October 2005) Isabelle Joumard

452. Raising Greece's Potential Output Growth (October 2005) Vassiliki Koutsogeorgopoulou and Helmut Ziegelschmidt

451. Product Market Competition and Economic Performance in Australia (October 2005) Helmut Ziegelschmidt, Vassiliki Koutsogeorgopoulou, Simen Bjornerud and Michael Wise

450. House Prices and Inflation in the Euro Area (October 2005) Boris Cournède

449. The EU's Single Market: At Your Service? (October 2005) Line Vogt

448. Slovakia's introduction of a flat tax as part of wider economic reforms (October 2005) Anne-Marie Brook and Willi Leibfritz

447. The Education Challenge in Mexico: Delivering Good Quality Education to All (October 2005) Stéphanie Guichard

446. In Search of Efficiency: Improving Health Care in Hungary (October 2005) Alessandro Goglio

445. Hungarian Innovation Policy: What's the Best Way Forward? (October 2005) Philip Hemmings

444. The Challenges of EMU Accession Faced by Catch-Up Countries: A Slovak Republic Case Study (September 2005) Anne-Marie Brook

443. Getting better value for money from Sweden's healthcare system (September 2005) David Rae

442. How to reduce sickness absences in Sweden: lessons from international experience (September 2005) David Rae

441. The Labour Market Impact of Rapid Ageing of Government Employees: Some Illustrative Scenarios (September 2005) Jens Høj and Sylvie Toly

440. The New OECD International Trade Model (August 2005) Nigel Pain, Annabelle Mourougane, Franck Sédillot and Laurence Le Fouler

439. The French Tax system: Main characteristics, recent developments and some considerations for reform (July 2005) Willi Leibfritz and Paul O’Brien

438. The Effects of EMU on Structural Reforms in Labour and Product Markets (July 2005) Romain Duval and Jørgen Elmeskov

437. Product Market Competition andEconomic Performance in New Zealand (July 2005) Annabelle Mourougane and Michael Wise 